\title{
Devociones reales e imagen pública en Sevilla*
}

\author{
Teresa Laguna Paúl \\ Universidad de Sevilla \\ teresalaguna@us.es
}

\section{RESUMEN}

El trabajo incide en el estudio de la Virgen de la Antigua y de la Virgen de los Reyes, dos representaciones relacionadas tradicionalmente con el rey Fernando III. Analiza los orígenes, la historia de esta vinculación, los espacios donde recibieron culto, patrimonio artístico y su significación con la imagen pública de la monarquía en la catedral mudéjar de Sevilla: el altar de la Antigua en la capilla de San Pedro y la capilla de los Reyes.

Palabras clave: Catedral de Sevilla, Virgen de la Antigua, Virgen de los Reyes, pintura gótica siglos XIII y XIV, escultura gótica, imágenes vestidas, capilla Real, simulacros y sepulcros reales, relicarios, tabernáculos góticos.

\section{Devotions' Kings and public images in Seville}

\begin{abstract}
The present work deals with the statues of "Virgen de la Antigua" (Our Lady of Antigua) and "Virgen de los Reyes" (Our Lady of Monarchs), two icons traditionally associated with King Ferdinand III of Castile. It analyses the origin and history of such association and the shrines built for those statues, their artistic heritage and their significance as emblems of the public image the Castilian monarchy tried to cast on the old "mudéjar" cathedral of Seville. Two shrines are studied, namely, those of the "Virgen de la Antigua" at Saint Peter's chapel, and the "Virgen de los Reyes", at the royal chapel.
\end{abstract}

Key wrods: Seville Cathedral, "Virgen de la Antigua", "Virgen de los Reyes", $13^{\text {th }}-14^{\text {th }}$ cent. gothic painting, $13^{\text {th }}$ gothic sculpture, dressed up statues, royal chapel, simulators, royal tombs, reliquaries, gothic tabernacles.

* Trabajo enmarcado en los resultados de los proyectos I+D HUM2006-12319/Arte del Ministerio de Educación y Ciencia (El reflejo de los nuevos cultos y devociones en las catedrales españolas durante el Barroco); I+D+i financiado por el Ministerio de Ciencia e Innovación (Un modelo digital de información para el conocimiento y gestión de bienes del patrimonio cultural). Agradezco a la Catedral de Sevilla el permiso para la reproducción del calzado de la Virgen de los Reyes. 
La culminación de la gran fase de expansión y conquista de la corona castellanoleonesa en el valle del Guadalquivir cambió profundamente la vida de las ciudades andaluzas y de sus habitantes durante siete siglos y abrió una nueva etapa histórica donde reconquistar equivalía a recristianizar, a reincorporar los territorios de las antiguas diócesis de la Bética al mundo occidental, a Roma. Un período decisivo, donde la campaña de Sevilla supuso recuperar para la cristiandad la antigua diócesis de san Isidoro. La Primera Crónica General informa del largo asedio que los castellanos impusieron a la ciudad de Isbilya y omite cualquier alusión a algún suceso de carácter sobrenatural o a cualquier hecho destacado en la vida del monarca relacionado con una visión de la Virgen en su campamento que, según la tradición, motivó una entrada furtiva en la ciudad y en la mezquita donde encontró una imagen mariana. Más tarde, otro día inmediato a la capitulación, repitió la incursión y, además, localizó cerca de la puerta de Córdoba el lugar de la sepultura de san Leandro, que el mismo santo le había revelado. La importancia de estos hechos extraordinarios constituyó una muestra de conformidad, del apoyo de la divinidad en la gran empresa reconquistadora donde la Virgen fue la privilegiada mediadora del monarca.

Estas tradiciones desarrollaron las devociones a la Virgen de los Reyes y a la Virgen de la Antigua, que tienen altares erigidos en la catedral de Sevilla y cuyos legendarios orígenes permanecieron en la memoria de los fieles durante generaciones y, sin duda, los escuchó Jerónimo Müntzer cuando visitó la ciudad de Sevilla y su catedral en 1494:

“Al salir del alcázar, fuimos a oír misa a una capilla que hay detrás de la mayor de la catedral, en donde están los suntuosos sepulcros de los reyes de Castilla.

Cuéntase que Don Fernando III era devotísimo de Nuestra Señora, creyendo firmente que con su ayuda lograría apoderarse de Sevilla, y así, mandó hacer una imagen de madera con todos sus miembros móviles y otra de Jesucristo sentado en un sitial, fabricada con el mismo arte; se agrega que de tiempo inmemorial guardaban los moros en su mezquita otra efigie de María que quitaron a los cristianos y que no se atrevían a destrozar, porque los que lo intentaron habían quedado o ciegos, o sordos, o con alguna otra lesión. Al rey, durante el sueño, le fue revelado que, dando a esta imagen ferviente culto, conseguiría la conquista de Sevilla, y habiéndolo hecho así, en poco tiempo entró victorioso en la ciudad. Vimos una escultura que representaba a don Fernando III con su esposa, que era alemana; otra de su hijo don Alfonso; una corona de la Virgen, obrada de oro purísimo, con esmeraldas, zafiros y otras piedras preciosas; tuvímosla en la mano y pudimos comprobar su peso considerable. El rey llevó en todas sus campañas la imagen a la que corresponde esta corona, porque la profesaba singular devoción y por intercesión de Nuestra Señora siempre obtuvo la victoria sobre los sarracenos" $"$.

Este testimonio sintetiza la procedencia y orígenes de ambas, aporta datos de interés respecto a los simulacros reales y enseres de la capilla Real que, por enton-

1 J. PUYOL, “Jerónimo Münzer. Viaje por España y Portugal en los años 1494 y 1495. (Conclusión) / versión del latín por Julio Puyol”, Boletín de la Real Academia de la Historia, 84 (1924), pp. 202-203. 
ces, estaba interinamente instalada en unas dependencias del patio de los Naranjos, próximas al espacio del altar mayor de la catedral terminado de construir en 1506. Sus palabras son un magnífico preámbulo para este trabajo de las devociones reales y la imagen pública en la Sevilla.

\section{“Dios abrirá. Rey entrará" 2}

La Primera Crónica General describe la capitulación de la ciudad y menciona la entrada solemne del monarca en el contexto de una ceremonia que concluyó con un pontifical en la "yglesia de Santa María", que presidiría alguna imagen de Nuestra Señora pero omite cualquier mención a la intervención de la Virgen y, evidentemente, a las devociones e imágenes conservadas de la Virgen de los Reyes o de la Virgen de la Antigua. En tres ocasiones las Cantigas de Alfonso X relacionan directamente a sus progenitores con sucesos extraordinarios de carácter mariano, pero tampoco hay referencia expresa a la devoción o a los milagros de la Virgen de la Antigua o a cualquier episodio de la vida de Fernando III vinculado con Ella. Sin embargo, la cantiga 221 cuenta cómo Fernando III, siendo niño, sanó después que su madre rezase ante una imagen de la Virgen venerada en el monasterio de Oña, la 256 indica que la reina Beatriz fue curada de una grave dolencia tras besar una imagen de Santa María "mui ben feita de metal", y la 292 vincula estrechamente una aparición post mortem del rey Fernando III al orfebre que había realizado varios trabajos para la capilla Real de Sevilla y le ordena colocar su anillo en la mano del Virgen cuya imagen cobra vida en la narración ${ }^{3}$.

Este silencio y exclusión de cualquier suceso de la vida de Fernando III relacionado con la Virgen de la Antigua hace suponer que muchos episodios inmediatos a la conquista de Sevilla se forjaron tiempo después. No obstante en su leyenda existen similitudes con otras hagiografías medievales como los Miráculos romanzados de Santo Domingo de Silos, escritos por Pedro Marín, que describen la aparición nocturna de este santo a los cautivos, su invisibilidad ante los enemigos o la facilidad para penetrar en edificios sin ser percibido por nadie. A finales de la Edad Media, la fama de santidad de Fernando III era un hecho, recogido en el De rebus Hispaniae Memorabilibus de Lucio Marineo Sículo, pero cualquier detalle relativo a su vida y milagros únicamente puede buscarse en su historiografía particular o en la de su Metropolis Totius Hispaniae, como señaló acertadamente Juan Luis Carriazo. Tiempo después, los historiadores del siglo XVI recogieron por escrito estos episodios pero fue, verdaderamente, en el periodo barroco cuando gozaron de mayor difusión en sintonía con la elaboración del expediente de canonización en-

2 Inscripción de la llave conmemorativa que entregó, según la tradición, la comunidad judía al rey Fernando III. D. ORTIZ DE ZÚÑIGA, Anales eclesiásticos y seculares de la muy noble y muy leal ciudad de Sevilla, [...]ilustrados y corregidos por Antonio María Espinosa y Carzel, Madrid 1795, (Reed. Sevilla 1988), T. 1, pp. 54-55; Catedral de Sevilla, Inv. 4109101110137.000; T. LAGUNA PAÚL, "Llaves de la ciudad de Sevilla", I.G. BANGO (coord.), Memoria de Sepharad, Madrid, 2002, p. 266.

3 W. METTMANN, Alfonso X, el sabio. Cantigas de Santa María, Madrid, 1986, T. II, pp. 284-286, 365366; T. III pp. 77-81. 
viado a Roma y con la aprobación de su culto el día tres de marzo de 1671, cuando todo lo relativo al santo rey se había convertido en una cuestión de fe ${ }^{4}$.

En la tercera década del siglo XVI el bachiller Luis de Peraza elaboró estas tradiciones en su Tratado de la Fundación y milagros de esta Santa Capilla del Antigua y en la Historia de Sevilla cuyas copias manuscritas consultaron, y analizaron sistemáticamente los historiadores desde Alonso Morgado y Rodrigo Caro a Diego Ortiz de Zúñiga y Nicolás Antonio entre otros. La primera obra no ha llegado hasta nuestros días pero en la segunda se indica que la imagen de la Virgen de los Reyes estaba en la tienda de campaña de Fernando III y que después de orar ante ella, entró en la ciudad sin ser visto y penetró en la mezquita "hacia aquella parte donde estaba y está nuestra Señora de la Antigua", una imagen que había permanecido sin ser destruida durante toda la ocupación islámica ${ }^{5}$. Los episodios legendarios de la Virgen de la Antigua -Aparición de la Virgen a los musulmanes, la caída del muro que ocultaba la imagen, la visita nocturna de Fernando III a la Virgen-, y la minuciosa descripción del traslado del pilar donde estaba pintada los recogió el jesuita Francisco Ortiz en su Discurso historial de la Antigüedad y Milagros de N. Sra. De la Antigua (1687) e inspiraron las publicaciones de Alonso Carrillo de Aguilar o de Antonio Solís y Ribadeneyra S.J. en el siglo XVIII, cuando la leyenda de la Antigua alcanzó su máximo apogeo y el arzobispo Luis de Salcedo y Azcona promovió toda la reforma barroca de la capilla. La imagen medieval fue pintada en el frente interior de un pilar almohade situado a la entrada de la capilla de san Pedro en la primitiva catedral mudéjar, frente al antiguo mihrab que no derribó la construcción de la catedral gótica, y se mantuvo en el mismo soporte hasta que el arzobispo Don Cristóbal de Sandoval y Rojas encargó al arquitecto Asensio de Maeda el traslado e instalación de este pilar de la Antigua en frente de la capilla donde recibe culto desde1578, y que incorporan después al retablo de mármol contratado con Pedro Duque Cornejo en $1734^{6}$.

La pintura medieval (fig.1), enmarcada en este retablo barroco, supera el tamaño natural, alcanza $321 \mathrm{~cm}$. de altura por $116 \mathrm{~cm}$. de ancho, y tiene un carácter monumental predeterminado, en origen, por la superficie libre del pilar almohade donde realizaron el mural en el último tercio del siglo XIV. Las intervenciones posteriores y su pervivencia en el edificio gótico forjaron un halo de misterio entorno a esta imagen que representa a la Virgen con el Niño de pie, coronada por ángeles al vuelo que tiene una donante a los pies, identificada a partir del siglo XVII con Doña Leonor de Albur-

4 J.L. CARRIAZO RUBIO, "Un episodio extraordinario en la historiografía de Fernando III", M. GONZÁLEZ JIMÉNEZ (coord.), Sevilla 1248, Madrid, 2000, pp. 747-748.

5 L. DE PERAZA, Historia de Sevilla, Lib. Décimo, cap. XXII, S.M. PÉREZ GONZÁLEZ (ed.), Sevilla, 1997, vol. II, pp. 230-231; D. ORTIZ DE ZÚÑIIGA, op. cit., 1795, T. 1, p. 28

6 Para la reforma de la capilla y ciclo pictórico: E. VALDIVIESO, "Pinturas de Domingo Martínez en la capilla de la Virgen de la Antigua en la catedral de Sevilla", Laboratorio de Arte, 3 (1990), pp. 109-121; A. RECIO MIR, “Asensio de Maeda y la transformación de la capilla de la Antigua de la catedral de Sevilla”, Cuadernos de Arte de la Universidad de Granada, 29 (1998), pp. 51-67; y "La llegada del Renacimiento a Sevilla: el proyecto del Cardenal Hurtado de Mendoza para la capilla de la Antigua de la catedral", Archivo Español de Arte, 73 (2000), pp. 176-190; F. PEREDA ESPESO, Las imágenes de la discordia. Política y poética de la imagen sagrada en la España del cuatrocientos, Madrid, 2007, pp. 152-158; A. JIMÉNEZ MARTÍN, "Rarezas de la Capilla de la Antigua", La piedra postrera. V Centenario de la conclusión de la catedral de Sevilla, A. JIMÉNEZ MARTÍN (Ed.), Sevilla, 2007, vol. II, pp. 401- 420. 
querque (1374-1435), casada en 1393 con el infante Don Fernando de Antequera. La imagen, de marcado eclecticismo, deriva iconográficamente de la Hodegetria bizantina y sigue los prototipos elaborados en la imaginería gótica occidental del siglo XIII con influencias de la pintura italiana, fundamentalmente sienesa, del mismo periodo 7 . Estas características las presentan otras dos pinturas murales conservadas en Sevilla, cuyos tamaños también quedaron condicionados por la superficie muraria donde se emplazaron: los altares de la Virgen del Coral de la iglesia de San Ildefonso y, especialmente, el de la Virgen de Rocamador de la parroquia de San Lorenzo, y debió ser habitual en la Andalucía occidental hasta entrado el siglo XV ${ }^{8}$. Su dilatada historia y tradiciones dificultan conocer fehacientemente el origen preciso de su advocación en la catedral, pero realizaré una aproximación a su devoción pública.

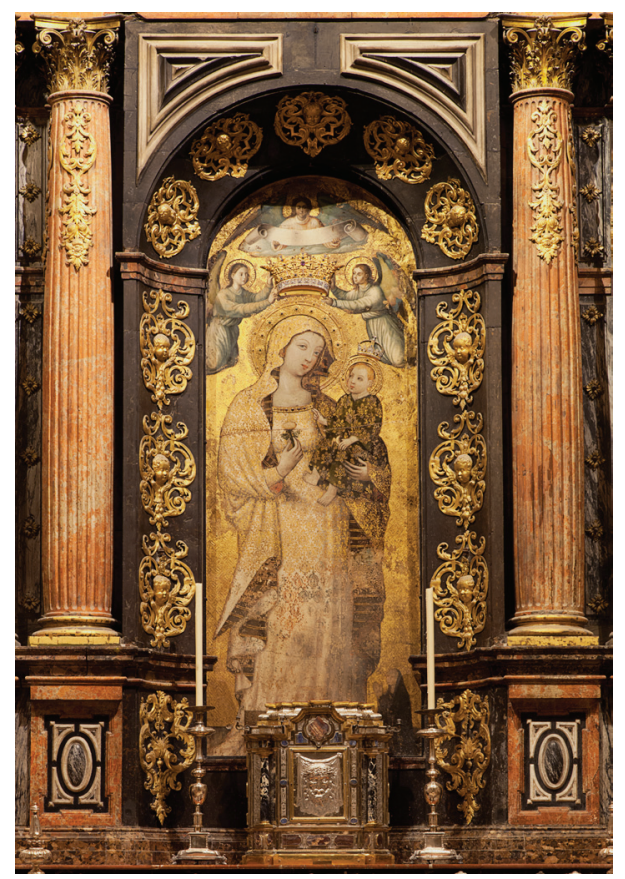

Fig. 1. Catedral de Sevilla. Virgen de la Antigua.

El terreno donde el califa Abū Ya'qūb Yūsuf decidió construir la nueva aljama de Isbiliya se asentó en un área pantanosa hasta la época del califato de Córdoba, urbanizada más tarde al levantar un barrio nuevo cuyas casas, oratorios, mercados y

7 J.M. MEDIANERO HERNÁNDEZ, Nuestra Señora de la Antigua. La Virgen 'Decana' de Sevilla, Sevilla, 2007, pp. 21-64.

8 T. LAGUNA PAÚL, "Notas sobre pintura gótica sevillana. El testimonio de Lucas Valdés", Laboratorio de Arte, 10, 1997, pp. 69-70. 
jardines extramuros se expropiaron en 1172 y se nivelaron inmediatamente con una potente cuña que garantizó la estabilidad del oratorio islámico. Las excavaciones no han encontrado, todavía, testimonios relacionados con lugares de culto que permitan suponer un origen cristiano anterior a la conquista, paleocristiano o visigodo ${ }^{9}$. Los investigadores del siglo XX observaron en el carácter trecentista de su representación, en su marcado eclecticismo y en su iconografía un prototipo bizantino cuyos rasgos fundamentales mantuvo el artista que realizó la pintura mural conservada ${ }^{10}$. La posible existencia de un icono modelo-anterior, algunas tradiciones de la Antigua relacionadas con otras leyendas o con milagros marianos acaecidos en santuarios de Tierra Santa recogidos en las Cantigas, y la legendaria vinculación del icono de la Virgen de la Seo de Valencia con Jaime I como la imagen mariana que presidió la primera misa después de la conquista, cobran fuerza en la búsqueda de un prototipo para la Virgen de la Antigua entre las devociones reales y el culto público en la Sevilla bajomedieval ${ }^{11}$.

La Primera Crónica General informa ampliamente del asedio y cerco de Isbiliya durante catorce meses, de su capitulación el 23 de noviembre del 1248, y de la entrada solemne en la ciudad cuando celebraron un gran pontifical, el 22 de diciembre, en la antigua aljama que, convenientemente purificada, habrían preparado para la consagración del altar. La misma fuente omite -en esta ocasión y en otras relativas a las conquistas de Toledo, Córdoba o Jaén- la existencia de imágenes durante estas ceremonias que, sin embargo, existieron y permanecieron en la memoria colectiva durante toda la Baja Edad Media hasta que las recogieron los historiadores del $1500^{12}$. En la consagración de la mezquita-catedral, el espacio ceremonial del altar mayor se situaría en el núcleo central del espacio islámico, orientado a levante e inmediato a la nave mayor de la aljama, porque su mayor amplitud facilitaba el desarrollo del culto y, sobre todo, quebró cristianamente el eje de la oración islámica hacia el mihrab. Esta ubicación en el centro del oratorio repitió los mismos hábitos realizados en la consagración de la catedral de Córdoba el 29 de junio de 1236, donde la capilla mayor quedó dispuesta al comienzo de la ampliación de al-Hakan II, convirtiendo sus lucernarios en el nuevo referente luminoso para el culto cristiano y las arcadas de las naves occidentales en el espacio destinado a los fieles ${ }^{13}$. Con anterioridad, la prepara-

9 Para una síntesis de la bibliografía y los hallazgos de la mezquita mayor de Sevilla hasta el 2007 véase A. JIMÉNEZ MARTÍN, "Notas sobre la mezquita mayor de la Sevilla almohade", Artigrama, 22 (2007), pp. 131-158. Para la actualización de los trabajos arqueológicos consultar las investigaciones difundidas por los ponentes en el Aula Hernán Ruiz (www.aulahernanruiz.com).

10 J. GUERRERO LOVILLO, Guía de Sevilla, Barcelona, 1962, p. 52; y “Arte”, Andalucía, Barcelona, 1980, vol. I, p. 327; J.M. MEDIANERO HERNÁNDEZ, op. cit., 2007, pp. 45-46.

11 N. BLAYA ESTRADA (coord.), Oriente en Occidente. Antiguos iconos valencianos, Valencia, pp. 14ss, 233.

12 Primera Crónica General, R. MENÉNDEZ PIDAL(ed.), Madrid, 1906, T. I, pp. 766-767; L. DE PERAZA, Historia de Sevilla, Sevilla, 1997 (1535), T. I, pp. 230-232

13 T. LAGUNA PAÚL, "Dos fragmentos en busca de autor y una fecha equívoca. Alonso Martínez, pintor en Córdoba a mediados del siglo XIV y las pinturas de la capilla de Villaviciosa", Laboratorio de Arte, 18 (2005), pp. 81-84. J.C. RUIZ SOUZA, "Las capillas reales funerarias catedralicias de Castilla y León: nuevas hipótesis interpretativas de Sevilla, Córdoba y Toledo", Anuario del Departamento de Historia y Teoría del Arte, 16 (2006), p. 20; T. LAGUNA PAÚL, "Una capilla mía que dicen de los Reyes. Memoria de la Capilla 
ción de esta ceremonia conllevó eliminar del oratorio islámico cualquier objeto o elemento del mobiliario relacionado con el Islam, abandonado por los almohades en su salida de la ciudad, pero en el transcurso de los preparativos pudieron colocar alguna imagen portátil, algún icono, en el interior de la maqsura que fuera el origen de las leyendas y, presumiblemente, del modelo del mural gótico pintado en el siglo XIV.

El culto y devoción a los iconos se difundió por occidente a partir de la conquista de Constantinopla en 1204. En la península Ibérica estaba muy extendido en la primera mitad del siglo XIII, cuando surgieron nuevas tradiciones y leyendas que rodean a la mayor parte de estas obras llegadas desde Bizancio o desde la península italiana, donde la "maniera greca" evolucionó en el transcurso de la misma centuria. Los códices de las Cantigas de Santa María aportan noticias de algunos venerados en el Mediterráneo oriental (cantigas 9, 34 y 46), del que recibe culto en la ciudad de Foggia en la Puglia (135) y del de Nuestra Señora de Salas (179), santuario de peregrinación mariana en la diócesis de Barbastro vinculado estrechamente a la Corona de Aragón ${ }^{14}$. La afluencia y conocimiento directo de estas obras en Castilla estuvo favorecido por las peregrinaciones, las embajadas y las relaciones familiares con los emperadores bizantinos desde el matrimonio de Juan de de Brienne con Berenguela, hermana de Fernando III, en 1224. Años más tarde, el monarca castellano acudió en auxilio del emperador Balduino II, casado con su sobrina María, enviándole expediciones para combatir a los cismáticos griegos que organizó Pelay Correa, maestre de la Orden de Santiago y protagonista activo en la conquista de Sevilla. Estos vínculos continuaron en época de Alfonso X cuando armó caballeros a dos hijos de su tía Berenguela, que vinieron en octubre de 1254 a los esponsales de la infanta Leonor de Castilla con el futuro Eduardo I de Inglaterra en las Huelgas de Burgos. Las pretensiones del rey Sabio al Imperio o la protección concedida a los comerciantes extranjeros radicados en Sevilla en 1260 facilitarían la circulación de iconos y piezas orientales en la península mediante compras directas o de obsequios diplomáticos ${ }^{15}$. Estas circunstancias y las alianzas del emperador Balduino II con el maestre de la Orden de Santiago inducen a pensar que el propio Pelay Correa recibiría algún icono. La presencia de éstos en la corte y su carácter portátil favorecería su existencia en Sevilla donde pudieron colocar alguno en el interior de la maqsura de la aljama para sacralizar figurativamente uno de los pilares situado frente al mihrab (Fig. 2).

Estas estrategias de conquista deberíamos hacerlas extensibles a las antiguas mezquitas de los barrios que, poco a poco, desde el primer reparto general de 1248 fueron purificadas y consagradas para atender las necesidades espirituales de los nuevos

Real de la catedral mudéjar de Santa María de Sevilla", A. JIMÉNEZ MARTÍN (coord.), La capilla Real. XIX edición del Aula Hernán Ruiz, Sevilla, 2012, pp. 181-182.

14 F. GUTIÉRREZ BAÑOS, "Pintura monumental en tiempos del Códice Rico de las Cantigas de Santa María", L. FERNÁNDEZ FERNÁNDEZ y J.C. RUIZ SOUZA (dir.), Alfonso X el Sabio 1221-1284. Las Cantigas de Santa María, Códice Rico, Ms. T-I-1, Real Biblioteca del Monasterio de San Lorenzo de El Escorial, Madrid, 2011a, T. II, pp. 391-395; L. MOLINA LÓPEZ, "Viaje a Italia a través de las Cantigas de Alfonso X”, Anales de Historia del Arte, 319-320 (2001), p. 326.

15 F. CORTI, "Iconos dentro de las miniaturas de las Cantigas de Santa María, El Mediterráneo en el arte. Actas del XI Congreso Español de Historia del Arte (Valencia, 1996), Valencia, 1998, pp. 8-12; E. BENITO RUANO, "La orden de Santiago y el Imperio Latino de Constantinopla", Hispania, 12 (1952), pp. 3-36. 


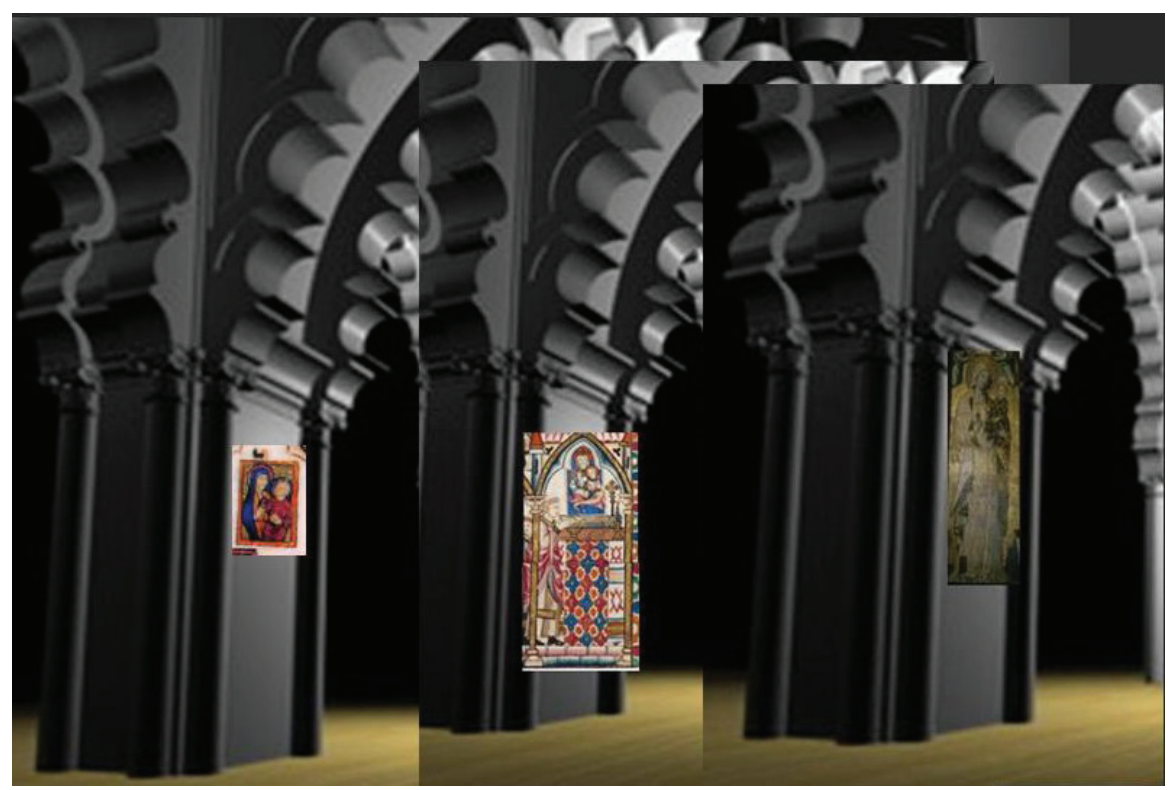

Fig. 2. Hipótesis de la génesis visual e iconográfica del altar de la Virgen de la Antigua en la capilla de San Pedro de la catedral de Sevilla. Reconstrucción capilla Antonio Almagro e iconos del Códice Rico de El Escorial. (C) Teresa Laguna.

pobladores, y a los edificios otorgados a las ordenes militares y religiosas, aunque hasta 1252 la diócesis careció de los inmuebles que le permitieron desarrollar canónicamente la estructura parroquial ${ }^{16}$. Estas mezquitas se purificarían y en ellas se consagrarían los nuevos templos donde, con los conocidos cambios funcionales del espacio, se dispondrían los objetos y libros necesarios para el culto y seguramente alguna imagen, pintada o esculpida, que canalizaría las necesidades espirituales, las devociones más arraigadas de los conquistadores y de los repobladores castellanos, leoneses, cántabros, aragoneses, valencianos o catalanes, entre otras procedencias que traerían consigo placas metálicas de devoción y amuletos prendidos a su cuerpo, imágenes de seriadas de pequeño formato y, entre otros, iconos cuya portabilidad permitió con facilidad disponer improvisados oratorios en las tiendas del campamento. El universo figurativo de las Cantigas permite reconstruir el aspecto de los primeros oratorios y templos hispalenses que tendrían alguna imagen en la puerta de acceso, los altares forrados con azulejería que cubrirían con paños ricos en las celebraciones, la silueta de los relicarios que veneraban los fieles, las esculturas de santos como san Miguel o Santiago el Mayor que recibieron culto y, evidentemente, las imágenes de

16 En el proceso del repartimiento en Sevilla se distinguen tres momentos: el primero fue el reparto general que acometió desde 1248 Fernando III y terminó Alfonso X en 1253; el segundo atañe a las fincas rústicas y urbanas (heredamientos) abandonados por sus propietarios entre 1255 y 1257; el tercero de 1263 redistribuyó casas abandonadas y yermas. Vid. J. GONZÁLEZ, El repartimiento de Sevilla, Sevilla, 1951. 
Cristo crucificado y de su Madre; esculturas, sencillas pinturas murales y pinturas sobre tabla que corresponderían a iconos bizantinos, griegos o italianos ${ }^{17}$.

En la catedral mudéjar de Sevilla, como en la de Córdoba, todo el espacio de la antigua maqsura formó parte de la capilla de San Pedro, que comprendía los tramos inmediatos al mihrāb y la cúpula que se elevaba sobre éste, descrita en la crónica de Ibn Sāhib al-Salā. Esta capilla acogió los enterramientos de la familia del noble alavés Ruy López de Mendoza, uno de los cinco partidores de Sevilla, cuyo rastro se pierde a partir de 1266 sin que, hasta la fecha, exista documentación relativa a su ajuar o a sus imágenes primitivas. En 1338 la capilla pasó a Ruy González de Manzanedo, viudo de una nieta de éste, permitiéndole el cabildo utilizar el primitivo nicho de la oración islámica -el antiguo mihrab- como sacristía, cerrar una puerta que comunicaba con el corral posterior y, entre otras obras, acotar todo el espacio de la capilla con un tabique que llegaría hasta el pilar donde estaba pintada una imagen de san Cristóbal. El acta notarial verifica la presencia de esta pintura en la cara norte del pilar $1-J$ de la aljama cristianizada pero omite cualquier mención a los altares del interior o a la existencia de una imagen mariana representada en la cara sur del mismo soporte, el que miraba al interior de la capilla ${ }^{18}$. Este silencio obedece, seguramente, al carácter contractual del documento que sólo precisó fijar los límites del cerramiento de la capilla y las obras necesarias para canalizar los nuevos accesos al corral posterior. Sin embargo el Libro Blanco de los aniversarios elaborado a partir de 1411, antes de comenzar la construcción gótica, para dejar constancia de las obligaciones y aniversarios que el cabildo tenía comprometidos, indica expresamente que el deán Don Pedro Manuel (†1393) fue enterrado delante del altar de Santa María de la Antigua y en esta capilla existía otro altar de "Sancta María de la Alcobilla" delante del cual sepultaron al canónigo Pero Alfonso, tesorero de la catedral en $1392^{19}$.

Esta mención del altar de la Antigua confirma la existencia de la pintura antes de 1411 cuando, seguramente, renovarían la imagen o el icono originario en el último tercio del siglo XIV y, previsiblemente, también su altar mudéjar. Desconocemos todavía qué pintor lo realizó o, incluso, qué persona promovió este encargo pero, sin duda, tuvo relación con la figura femenina representada en la parte inferior izquierda del altar cuya identidad permanece sin desvelar, aunque desde el siglo XVII fue asociada con Doña Leonor de Alburquerque, viuda desde 1416 de Fernando de Antequera, primer rey de su estirpe en el reino de Aragón y abuelo de Fernando el

17 F. GUTIÉRREZ BAÑOS, op. cit., 2011a, pp. 378-386, 391; y A. GARCÍA AVILÉS, “'Este Rey tenno que enos idolos cree': imágenes milagrosas en las cantigas de Santa María”, L. FERNÁNDEZ FERNÁNDEZ y J.C. RUIZ SOUZA (dir.), Alfonso X el Sabio 1221-1284. Las Cantigas de Santa María, Códice Rico, Ms. T-I-1, Real Biblioteca del Monasterio de San Lorenzo de El Escorial, Madrid, 2011, T. II, pp. 523-559.

18 R. SÁNCHEZ SAUS, Caballería y linaje en la Sevilla medieval, Sevilla, 1989, p. 305; T. LAGUNA PAÚL, "La aljama cristianizada. Memoria de la catedral de Santa María de Sevilla", A. MORALES MARTÍNEZ (dir.), Metropolis Totius Hispaniae, Madrid, 1998, p. 5; y A. JIMÉNEZ MARTÍN, Anatomía de la catedral de Sevilla, Sevilla, 2013, pp. 276-280.

19 Archivo de la Catedral de Sevilla (A.C.S), Sec. II, I. 1477, Libro de las heredades e mezquitas e bannos e carneçerias e dineros de la aduana que dieron los muy nobles [...] El qual compuso e ordeno Diego Martinez, prior e racionero de la dicha iglesia. Et acabose de escrevir sábado veynte e un dias del mes de febrero, anno del Nascimento de nuestro Salvador Jhesu Christo de mille e quatroçientos e honza annos, fol. $27 \mathrm{v}-28 \mathrm{v}$, Reg. $83,84,85,86$ y 89 
Católico. No obstante, la factura técnica unitaria del mural conservado corrobora la realización de la donante en sincronía con la Virgen de la Antigua que fue pintada aproximadamente a $120 \mathrm{~cm}$. del suelo, presidiendo un altar cuyo frente estaría cubierto por azulejos o con alguna composición geométrica realizada al fresco, que imagino semejante a la descubierta en el altar de Nuestra Señora de Rocamador en la parroquia de San Lorenzo ${ }^{20}$. (Fig. 2)

La devoción de la Virgen de la Antigua aumentó en el transcurso del siglo XV cuando, poco a poco, el culto también revitalizó las devociones a San Laureano, San Hermegildo y otros santos de época visigoda ${ }^{21}$. Este neovisigotismo o goticismo propiciado, entre otros, por el arzobispo Don Gonzalo de Ejea y el cardenal Don Juan de Cervantes, el gran devoto de la Virgen de la Antigua, evitó seguramente el derribo del pilar almohade y la desaparición de la imagen mariana que perpetuaría las tradiciones ancestrales recogidas por Jerónimo Müntzer durante su estancia en Sevilla.

Las predicaciones de Fray Hernando de Talavera y las medidas impuestas por las autoridades religiosas en Sevilla para controlar la religiosidad de su población conversa en 1478, hicieron de la Virgen de la Antigua un referente de las devociones de los cristianos viejos y de su factura unas leyendas semejantes a las de algunos iconos bizantinos o al milagro de las imágenes incisas en las columnas de la Natividad de Belén $^{22}$. La tradición que identifica a la donante con la reina Leonor fue recogida en los textos de época barroca y, especialmente, en la vida del Venerable Contreras $(† 1548)$ escrita por el jesuita Gabriel de Aranda en 1692, quien difundió la vinculación del infante Fernando de Antequera con esta devoción porque había fundado la Orden de la Jarra y del Grifo, cuya titular fue una copia de la Virgen de la Antigua que recibe culto en Medina del Campo. También indicó que cuando murió su viuda se hizo retratar a los pies de esta imagen sevillana donde acudía a rezar todos los días, pero todas las fuentes medievales omiten cualquier relación del infante con el altar de la Antigua de la catedral y, según el testimonio que aportó el humanista italiano Lorenzo Valla, la reina viuda oraba diariamente ante la Virgen del Socorro, la titular del templo sevillano de la misma advocación ${ }^{23}$.

20 En la restauración de 1991 se constató que la Virgen de la Antigua y su donante están realizadas con la misma técnica y preparación; agradezco y debo a Don Juan Abad Gutiérrez esta confirmación y el conocimiento directo de los restos encontrados en la intervención del altar y mural de la Virgen de Rocamador en 2012. J. M. MEDIANERO HERNÁNDEZ, op. cit., 2007, pp. 25-28.

21 T. LAGUNA PAÚL, "Un sacramentario sevillano de 1393”, Códice, 12 (1997), pp. 5-36; P. RUBIO MERINO, "Santoral mozárabe hispalense", Memoria Ecclesiae, 21 (2002), pp. 677-725; y J. PÉREZ-EMBID WAMBA, "La obra del P. Quintanadueñas en el contexto hagiográfico hispano", A. DE QUINTANADUEÑAS, Santos de la ciudad de Sevilla y su arzobispado (1637), Sevilla, 2006, pp. 5-15.

22 R. SÁNCHEZ AMEIJEIRAS, “'Ymagenes sanctae': Fray Juan Gil de Zamora y la teoría de la imagen sagrada en las Cantigas de Santa María”, M. ROMANÍ y M.A. NOVOA (coord.), Homenaje a José García Oro, Santiago de Compostela, 2002, pp. 515-525; F. PEREDA ESPESO, op. cit., pp. 29-31 y 145-248. La influencia de la cantiga 29 en la leyenda de la Antigua sería anterior al siglo XV; Juan II tenía el volumen en el Alcazar de Segovia y la Reina Católica lo regaló a su mayordomo Andrés Cabrera.

23 F. GUTIÉRREZ BAÑOS, "La corona de Castilla en la encrucijada: corrientes pictóricas en la Corona de Castilla en tiempos del infante don Fernando de Antequera", Artigrama, 26 (2011b), pp. 391-396. G. DE ARANDA (S.I.), Vida del siervo de Dios, ejemplar de sacerdotes, el venerable Padre Fernando de Contreras, natural de esta ciudad de Sevilla, del óbito clerical de Nuestro Padre San Pedro, Sevilla, 1692, pp. 383-386. 
Las estancias de los Reyes Católicos en Sevilla incrementaron, como es conocido, el fervor de la reina Isabel por la Virgen de la Antigua y la soberana católica, que asistía todos los sábados a rezar ante su efigie, donó en agradecimiento por el alumbramiento del príncipe heredero una lámpara de plata, dotada anualmente con seis quintales de aceite ${ }^{24}$. Los monarcas también demostraron interés por la terminación de la catedral gótica y, especialmente, por las obras de la capilla de los Reyes, cuyas imágenes, enseres, sarcófagos y simulacros reales permanecían en las estancias del patio de los Naranjos desde 1434. En esta capilla provisional la Virgen de los Reyes vestía las ropas de corte contemporáneas con algunas prendas regaladas o bordadas por la misma reina Isabel ${ }^{25}$.

\section{“Omagen da Virgen que ten vestido cendal”}

Esta imagen vestida de fino lino, mencionada expresamente en la cantiga 292, es la Virgen de los Reyes (fig.3), la escultura de Santa María cuya devoción está estrechamente vinculada a la personalidad de Fernando III, a su voluntad de reconquistar la antigua diócesis de san Isidoro para hacer de Sevilla la capital de sus dominios. Esta obra excepcional veló cristianamente el eterno reposo del santo rey desde 1252, en el altar mayor de la catedral mudéjar de Sevilla y después en la capilla Real erigida por Alfonso X, que en 1433 fue necesario desmantelar y trasladar provisionalmente a unas dependencias del patio de los Naranjos para llevar a cabo la construcción gótica. Concebida y realizada para tener apariencia de veraz Soberana celestial es, sin duda, la mejor escultura conservada del siglo XIII relacionada con unas tallas dotadas con precisos dispositivos mecánicos que les permitían cierta movilidad; admiradas por las cortes más refinadas fueron objeto de interés, de regalos e intercambios diplomáticos entre los soberanos y de fascinación de todos los fieles. Estas imágenes vestidas debieron ser habituales en el periodo gótico y el mismo Alfonso X habla en la cantiga 295 de un rey que tenía por costumbre ataviar y engalanar a la Virgen, cuya identidad se piensa correspondería a Fernando III $^{26}$.

La escultura, de tamaño natural, tiene el cuerpo cubierto de fino pergamino que evoca la anatomía de una doncella, mientras su cabeza y extremidades están poli-

24 D. ORTIZ DE ZÚÑIGA, op. cit., 1785, vol. III, p. 102.

25 T. LAGUNA PAÚL, "El Imperio y la corona de Castilla: la visita a la capilla de los Reyes sevillana en 1500", C. COSMEN, M.V. HERRAEZ y M. PELLON (coord.), El intercambio artístico entre los reinos hispanos y las cortes europeas en la Baja Edad Media, León, 2009a, pp. 225, 233-235. Para las obras góticas de la Capilla Real vid. A. JIMÉNEZ MARTÍN, op. cit., 2013, (en prensa) capítulo quince.

26 J. HERNÁNDEZ DÍAZ, Iconografía medieval de la Madre de Dios en el antiguo reino de Sevilla, Madrid, 1971, p. 9; W. METTMANN, op. cit., 1986, vol. III, pp. 110-112: “Que por al non devess'om'a Santa Maria servir, / Deve-o fazer por quan ben sabe serviçio gracir. / E daquest'un gran mirage vos quer'ora retraer / Que mostrou Santa Maria, per com'eu pud'aprender, / a un rei que sas figuras mandava sempre fazer / miut' apostas e flemosas; e fazia-as vestir. / Que por al non devess'om'a Santa Maria servir, [...] / De mui ricos panos d'ouro e de mui nobre lavor, / De põya-lles nas testas pera parecer mellor / corõas con muitas pedras ricas, que grand' esprandor / davan senpr' aa omagen e fazíana luzir. / Que por al non devess'om'a Santa Maria servir, [...] / E Outossi nas sas festas ar fazia-lle mudar / Senpr'outros panos mais ricos pola festa mais onrrar, / e ben assi as fazia põer sobelo altar; demais trobava per ela, segund'oy departir. [....]'. 


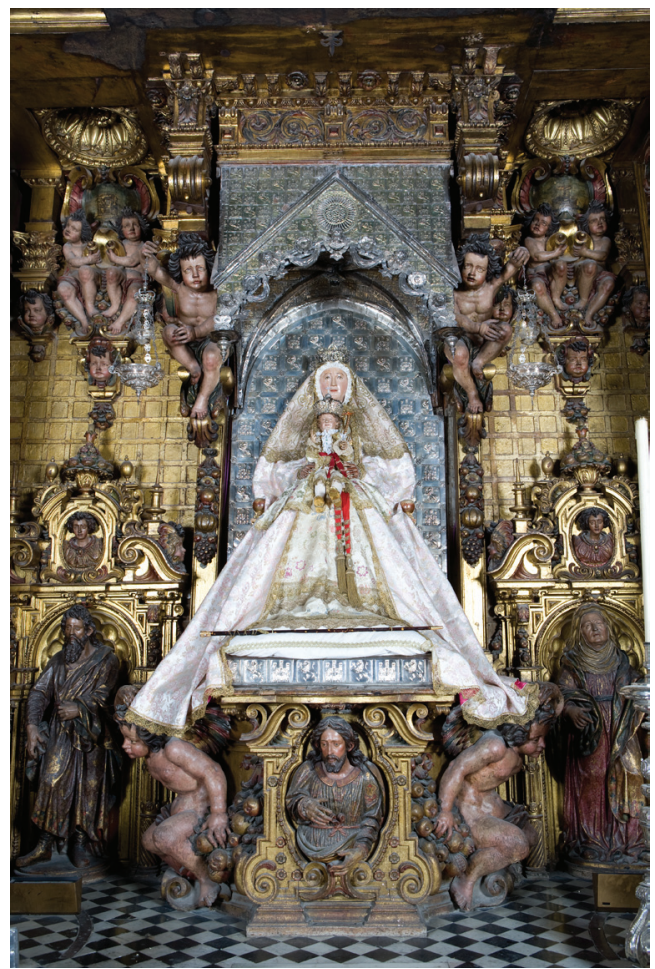

Fig. 3. Virgen de los Reyes. Catedral de Sevilla, capilla Real.

cromadas. El cabello forma una espesa y larga melena compuesta por hilos de oro muy desgastados, sujetos con finos clavos de madera al volumen de su cabeza. En su espalda existe una portezuela que cierra el hueco donde quedó instalada una rueda dentada, con su pletina de rotación y su cuerda de fleje correspondientes al mecanismo medieval de movimiento de la cabeza, inutilizado desde hace más de un siglo. Este dispositivo permitía cambiar la colocación del rostro y responde a la misma tipología que dibujó Villard de Honnecourt en el cuerpo de un águila cuya cabeza giraba cuando el diácono realizaba las lecturas y debió ser bastante habitual en el siglo XIII. Unos pasadores de madera permiten encajar la articulación de los brazos, flexionar las piernas y adoptar una posición sedente o levantarla; la forma de unir el antebrazo con la mano también facilita el cambio de postura y giro como ocurre, por ejemplo, en la Virgen de la Anunciación del Museo Nacional de Pisa o en el ángel del Museo Civico de Montalcino, fechadas en el siglo XIV ${ }^{27}$.

27 J. HERNÁNDEZ DÍAZ, La Virgen de los Reyes, patrona de Sevilla y su archidiócesis. Estudio iconográfico, Sevilla, 1947, (reed. 1996); J.ARQUILLOTORRES, Aspectos socio-religiosos dela conservación de las representaciones escultóricas marianas. Influencia de tres imágenes medievales representativas, Tesis Doctoral, Sevilla, 1989, pp. 155-158, 255-268, 404-488, 524-543, 593-597. T. LAGUNA PAÚL, "La Virgen 
La imagen, que alcanza $176 \mathrm{~cm}$. de altura, fue ideada y confeccionada para vestirla con ropas acordes a su rango y dar apariencia regia a quienes la contemplaran, sedente con el Niño apoyado en su regazo izquierdo mediante un perno, cuya huella todavía existe cerca de su cadera izquierda. Esta Reina celestial, ataviada con ropas heráldicas con las armas de Castilla y León, calza todavía unos zapatos de cordobán blanco decorados con una flor de lis roja en el empeine que tradicionalmente se vinculan con un origen francés, con un regalo de Luis IX a su primo Fernando III, y la historia le otorga un carácter legendario a su factura singular, angélica y aquiropoieta. Para Luis de Pereza y los historiadores del siglo XVI, esta imagen estaba en el campamento de Fernando III, acompañó al monarca en la entrada de Sevilla y presidió la primera misa en la catedral. En el siglo XVII el Abad Alonso Sánchez Gordillo, Pineda, Alonso Muñiz, Antonio de Quintanadueñas o José Maldonado Dávila y Saavedra indicaron que el rey santo imploró constantemente la intercesión de la Virgen y en una ocasión, durante la larga espera del asedio de Sevilla, cuando se retiró para rogar por el final de una sequía perniciosa tuvo una visión donde la Madre de Dios le anunció la próxima lluvia y le ofreció ayuda en la campaña contra los musulmanes. El monarca quiso plasmar figurativamente los rasgos de la Señora y encargó una figura esculpida en tres ocasiones sin que ninguna colmara sus deseos. Después llegaron al campamento tres jóvenes desconocidos ofreciendo sus servicios que trabajaron encerrados bajo llave. Transcurrido un tiempo, sin noticias ni presentación del trabajo, abrieron el local donde encontraron la escultura cubierta con un paño y ningún rastro de los escultores. El suceso, lógicamente, adquirió carácter sobrenatural, los jóvenes peregrinos se identificaron con ángeles, la Imagen con un regalo del Cielo y las tres esculturas desechadas forjaron los orígenes de la Virgen de las Aguas de la colegial del Divino Salvador, la Virgen de los Sastres de la parroquia de san Isidoro y la Virgen de los Reyes del convento de San Clemente ${ }^{28}$.

Su filiación artística es compleja pero equiparable a otras tallas francesas derivadas de los modelos de segundo cuarto del siglo XIII en Chartres. Con independencia de su excepcional factura, los zapatos que calza (fig. 4) son un trabajo hispano realizado en cordobán blanco, casi una piel de badana, con decoraciones confeccionadas con otra piel roja, teñida con cochinilla, recortada y unida con una exquisita costura manual por el reverso; un cordón trenzado de color dorado cobrizo rodea la línea superior de los dieciséis arquillos calados del empeine, puente y otros perdidos en el talón. Los zapatos miden $25 \mathrm{~cm}$., la pala está decorada con una flor de lis de color rojo rodeada por estrellas de ocho puntas, en el puente la palabra AMOR inserta con letras lombardas y en el talón otras dos estrellas flanquean una cruz cercada con cuatro aves del paraíso. José Gestoso consideró estos zapatos obra mudéjar e interpretó

de los Reyes”, I. BANGO (coord.), Las Maravillas de la España Medieval, León, 2001a, p. 435. Para las esculturas italianas véase Scultura dipinta. Maestri di legname e pittori a Siena 1250-1450, Florencia, 1987, pp. $56-60$ y $73-77$.

28 J. HERNÁNDEZ DÍAZ, op. cit., 1947, pp. 19-21 y 23-24; J. HERNÁNDEZ DÍAZ, Iconografía medieval de la Madre de Dios en el antiguo Reino de Sevilla, Madrid, 1971, pp. 9-14; A. MUÑIZ, Insinuación apologética al rey N. Sr. D. Carlos segundo, para su Santa y real capilla de la Ciudad de Sevilla en que discurre, y desenvuelven de las mezclas de la confusión que de su venerable antigüedad [..], Sevilla, 1686( I.C., Biblioteca Capitular y Colombina, ms. 57-3-40, fol. 63-83) 


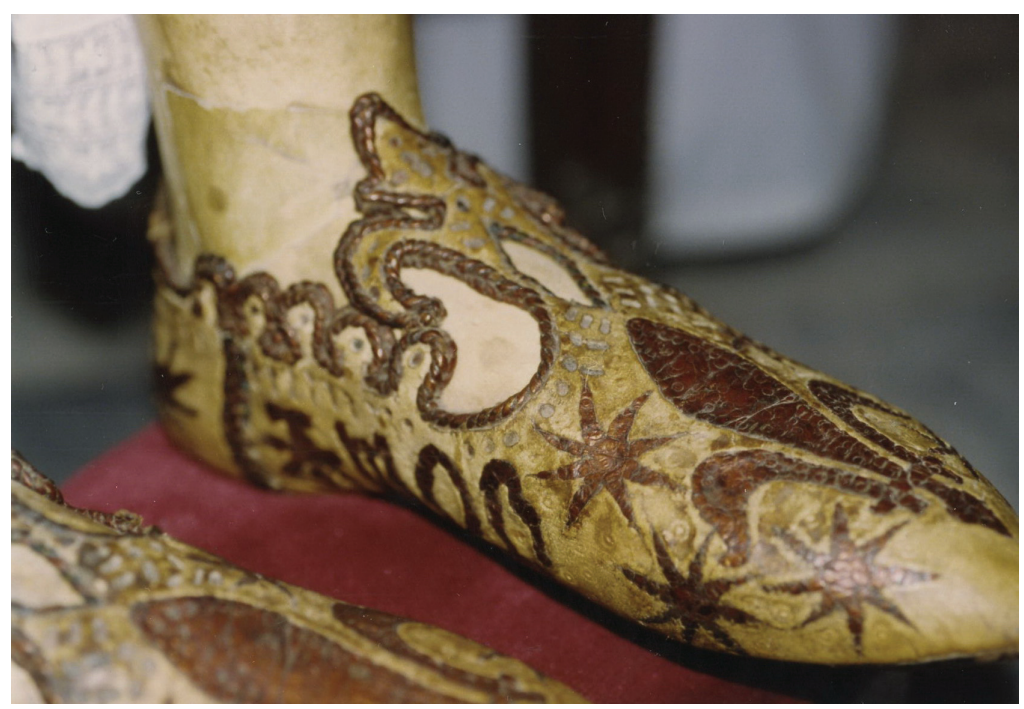

Fig. 4. Calzado de la Virgen de los Reyes. (C) Catedral de Sevilla y Teresa Laguna.

las flores de lis como un recuerdo de su procedencia francesa, al igual que todos los historiadores desde el siglo XVI ${ }^{29}$.

La dificultad para analizar este calzado extraordinario del siglo XIII y la complejidad de sus decoraciones hacen que carezca de estudios monográficos, aunque sus paralelos podrían localizarse en algunos zapatos litúrgicos confeccionados en guadamecí con incrustaciones de cueros de distinto color. Las ropas heráldicas que vestía esta imagen en el siglo XIII inducen a pensar que, originariamente, se corresponderían con los vestidos de la propia reina Doña Beatriz cuya corona nupcial llevó hasta su pérdida en 1873 (fig. 5), y que este calzado con la palabra AMOR tuviera el mismo origen regio ${ }^{30}$. Sin embargo éste debe vincularse directamente a la factura de la escultura, a su carácter cultual y, en definitiva, al universo de la espiritualidad que conduce al fervor mariano con mayúsculas; su manufactura complementa la iconografía de la Virgen de los Reyes. La flor de lis es un atributo mariano que alude también a la Trinidad, las estrellas de ocho puntas o flores del mismo número de pétalos suelen adornar el velo y los ropajes de numerosas vírgenes desde la plena Edad Media asociándose en la iconografía cristiana a la Estrella de la Mañana, a la Madre del Hijo de Dios que murió en la cruz y es la fuente de salvación, de resurrección y vida. Complemento indispensable para el culto de latría de esta imagen en el altar mayor de la catedral sería un baldaquino, templete o tabernáculo cuyas características originarias son desconocidas, ya que todas las fuentes posteriores mencionan un tabernáculo adscrito a las empresas de Alfonso X.

29 J. GESTOSO Y PÉREZ, Sevilla monumental y artística. Sevilla, 1890, T. II, pp. 326-328.

30 Para el ajuar medieval: T. LAGUNA PAÚL, op. cit., 2009a, pp. 224-235. 


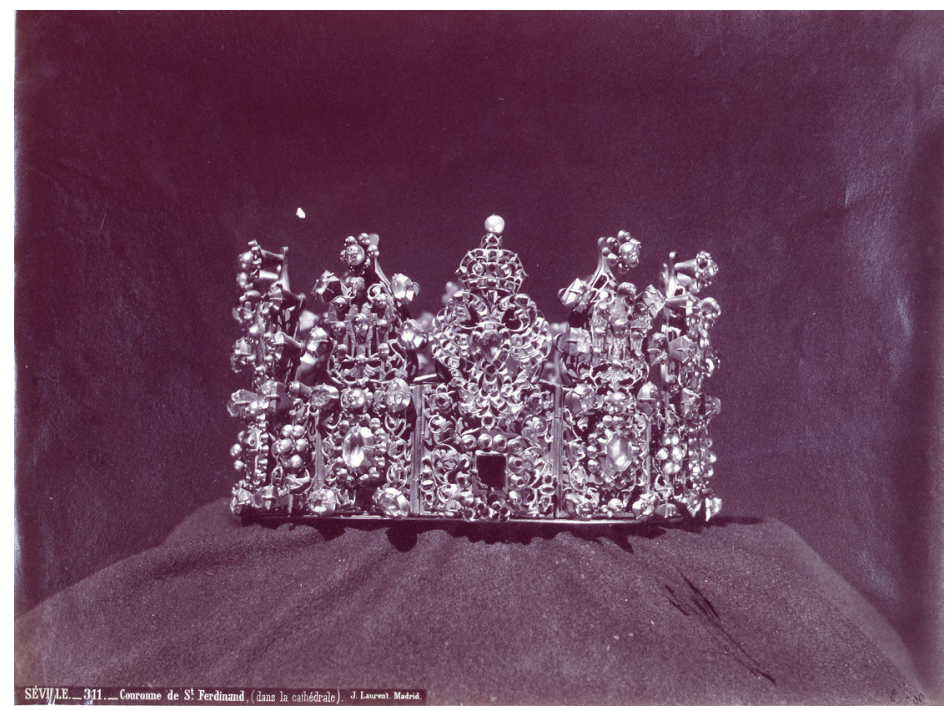

Fig. 5. Corona de la Virgen de los Reyes fotografiada por Jean Laurent en 1872. (C) Museo de Artes Decorativas, Madrid.

La elección del altar mayor de la catedral de Sevilla como espacio funerario de Fernando III supuso, desde el primer momento, la búsqueda de nuevos referentes ideológicos para la imagen pública de la dinastía castellano-leonesa, para la majestad del rey que desarrolló Alfonso X en su obra legislativa. Esta decisión descartó llevar a cabo el enterramiento en alguno de los panteones reales y fue capital en la historia de la catedral de Sevilla. Las amplias posibilidades que brindaban las diecisiete naves de una aljama-catedralicia y una diócesis recién dotada, que se honraba en convertirse en el lugar de reposo definitivo de un gran monarca, constituían un territorio idóneo y basto donde solemnizar, permanentemente, la sepultura del monarca que unificó definitivamente las coronas de Castilla y León. Una aljama cristianizada, cuyo altar mayor ocuparía en 1252 una superficie aproximada de $300 \mathrm{~m}^{2}$ en el área oriental del edificio, inmediata a la antigua nave mayor que conducía directamente a la capilla de San Pedro, al antiguo mihrab. Un espacio de representación donde las ceremonias religiosas adquirieron dimensión política para una dinastía que, en una etapa de autoafirmación, tenía como prototipo de monarca a Fernando III, para el cual Alfonso X exigió una constante veneración ${ }^{31}$.

En esta voluntad de cambio pudieron influir otros conjuntos funerarios contemporáneos como el de Eduardo el confesor en la cabecera de la abadía de Westminster,

31 A. RUCQUOI, "De los reyes que no son taumaturgos: los fundamentos de la realeza en España", Estudios de Historia y Sociedad, XIII-51 (1992), pp. 74-75; A. GUIANCE, Los discursos sobre la muerte en la Castilla medieval (siglos VII-XV), Valladolid, 1998, pp. 308-319; T. LAGUNA PAÚL, "La capilla de los Reyes de la primitiva catedral de santa María de Sevilla y las relaciones con la corona castellana con el cabildo hispalense en su etapa fundacional (1248-1285)", I. BANGO (coord.), Las maravillas de la España medieval, León, 2001b, pp. 237, 241-242; у op. cit., 2012, pp. 179-187. 
el panteón real de la basílica de Saint Denis reorganizado en época de Luis IX o los sepulcros de los reyes normandos en la catedral de Palermo, cuyas características se conocerían perfectamente por el matrimonio de Leonor de Castilla con Eduardo I de Inglaterra, por las estancias del infante Don Fadrique en la corte de su tío Federico II y por las de su hermano Don Felipe, el obispo electo de diócesis, en París ${ }^{32}$.

La dignificación de la memoria de Fernando III constituye uno de los aspectos mas destacados de la actuación de Alfonso X en la catedral de Sevilla quien, además, contó con la ayuda del pontífice Inocencio IV, que concedió indulgencias encaminadas a incentivar la presencia de los fieles en las grandes fiestas del calendario anual y la afluencia semanal a los cultos sabatinos de la Virgen con las oraciones por el alma del rey santo ${ }^{33}$. La actuación sevillana y la redacción del ideario alfonsí, legislado en las Partidas y el Espéculo, fue simultánea con otras de sus empresas artísticas que enaltecieron la memoria histórica de su dinastía y sus héroes más emblemáticos: la Sala de los Reyes del alcázar de Segovia, reconstruida a partir de 1258, los traslados de las sepulturas del rey Pelayo a Covadonga hacia 1270 y de Wamba desde Pampliega a la iglesia de Santa Leocadia en Toledo en 1272, la apertura de la tumba y nuevo monumento funerario encargado para el Cid en San Pedro de Cardeña y los cambios efectuados en el cementerio real de las Huelgas de Burgos, ubicando las sepulturas del fundador Alfonso VIII y de Leonor de Aquitania en el coro de la iglesia, cuyo altar quedó consagrado en noviembre de $1279^{34}$. En coordinación con esta última mudaron los restos de Beatriz de Suabia a la catedral de Sevilla donde recibieron sepultura junto a su marido Fernando III en el nuevo panteón antes del 11 de noviembre de $1279^{35}$.

El carácter de esta empresa sevillana superó con creces cualquier normativa legal porque desde el primer momento Alfonso X exigió para su progenitor una constante veneración, manifiesta en los actos de la conmemoración anual de la capitulación de Sevilla el 23 de noviembre, día de San Clemente, y del aniversario de Fernando III en la catedral de Sevilla, a partir de 1254 y 1260 respectivamente. En el transcurso

32 T. LAGUNA PAÚL, op. cit., 2012, pp. 183

33 J. SÁNCHEZ HERRERO, C. ÁLVAREZ MÁRQUEZ, "Fiestas y devociones en la catedral de Sevilla a través de las concesiones medievales de indulgencia”, Revista española de derecho canónico, 46 (1989), p. 133, doc. 2 y 3; T. LAGUNA PAÚL, op. cit., 1998, p. 58; у op. cit. , 2012, pp. 185.

34 ALFONSO X, Leyes de Alfonso X. I Espéculo, G. MARTÍNEZ DÍEZ (ed.), Ávila, 1985, Lib. II, Título XVI, ley II: "Quel lugar o rrey fuere soterrado, que debe ser onrado e guardado en todas las cosas assi como las cosas del rey bivas que á por todo el reyno, e esto por onrra del rey que y yaze"; R. CÓMEZ RAMOS, Las empresas artísticas de Alfonso X el sabio, Sevilla, 1979, pp. 127-129; T. LAGUNA PAÚL, op. cit, 1998, pp. 58-59; R. SÁNCHEZ AMEIJEIRAS, “El 'çementerio real' de Alfonso VIII en las Huelgas de Burgos”, Semata, 10 (1999), pp. 77-110; R. IZQUIERDO BENITO, “Alfonso X el sabio, ¿primer arqueólogo medievalista?”, Historia, Instituciones y Documentos, 28 (2001), pp. 231-240; O. PÉREZ MONZÓN, "Iconografía y poder en Castilla: las imágenes de Alfonso VIII", Anuario del Departamento de Historia y Teoría del Arte, 14 (2002), pp. 19-41; R. ALONSO ÁLVAREZ, "De Carlomagno al Cid: la memoria de Fernando III en la capilla Real de Sevilla", Fernando III y su tiempo (1201-1525), Ávila, 2003, pp. 471-505; y "Los enterramientos de los Reyes de León y Castilla hasta Sancho IV”, e-Spania [en red] 3 (2007), pp. 6-7.

35 J.M. LIZOAIN GARRIDO, Documentación del monasterio de las Huelgas de Burgos (1263-1283), Burgos, 1987, p. 113. J. MARTÍNEZ DE AGUIRRE, "La primera escultura funeraria gótica en Sevilla: la capilla Real y el sepulcro de Guzmán el Bueno (1248-1320)", Archivo Español de Arte, 270 (1995), pp. 118119; M. GONZALEZ JIMÉNEZ, Diplomatario andaluz de Alfonso X, Sevilla, 1991, doc. 45; y T. LAGUNA PAÚL, op. cit., 2001b, pp. 241-243 
de la ceremonia religiosa que recuerda la capitulación y celebra la reincorporación de Isbiliya a la cristiandad el 23 de noviembre de 1248, a la que acude todavía el Ayuntamiento, el Concejo de la ciudad, una espada del rey Fernando III es objeto de veneración y su estandarte real, el que tremoló en el alminar de la aljama el día de la capitulación, constituye otro de los elementos centrales de la procesión litúrgica con algunos cambios por el paso de los siglos ${ }^{36}$. Los actos del aniversario de Fernando III descritos en la Primera Crónica General muestran una ceremonia religiosa con tal solemnidad que recreaba, prácticamente, las exequias fúnebres del monarca y sus cuantiosas dotaciones explican aspectos importantes en la evolución de las ceremonias, en la génesis de la capilla de los Reyes y del segundo altar mayor de la catedral mudéjar $^{37}$.

Para el aniversario prepararían el altar mayor de la catedral con el ajuar más emblemático que entonces tuviera el templo $\mathrm{y}$, aunque el texto lo omite, la presencia del estandarte real destacaría, respecto a los demás, muy cerca de la losa sepulcral que, posiblemente, cubriría algún paño heráldico. El amplio número de asistentes, el empleo de armerías y pendones, el gran volumen de hachones de cera seguramente armoriados, así como la presencia de los cien peones del rey Aben Alhamar formando una guardia de luz alrededor de la sepultura ocuparían un amplio espacio en el interior del templo que cada 30 de mayo obligaría, necesariamente, a destacar visualmente a los fieles la posición de la sepultura y a disponer, quizás, alguna estructura portátil para esta ceremonia semejante a una capella ardente, a un castrum doloris $\mathrm{o}$, incluso, rodear la tumba con alguna cancela baja de madera o hierro ${ }^{38}$.

Esta conmemoración y su parada militar gestó necesidades espaciales, cambios significativos alrededor del altar mayor o de Santa María donde estuvo la losa sepulcral de Fernando III hasta que fue sustituida por un monumento, que mencionó Fray Juan Gil de Zamora en una biografía incompleta de este rey escrita hacia 1270. También el cabildo, poco a poco, evolucionó y elevaría otras demandas al monarca que terminaron por diferenciar dos grandes capillas en el centro de la aljama cristianizada, a partir de 1261 y llevadas a cabo o, al menos, iniciadas aproximadamente en 1268 cuando Alfonso X dejó al arzobispo don Remondo al cargo de la organización definitiva de la diócesis y su templo mayor para terminar la conquista de Andalucía

36 J. GESTOSO Y PÉREZ, op. cit., T. II, 351-352; I. HERRÁEZ MARTÍN, "La espada de Fernando III, el santo", Laboratorio de Arte, 15 (2002), pp. 335-348; T. LAGUNA PAÚL, op. cit., 1998, pp. 130-132; y "La espada de Fernando III el santo", I. BANGO (coord.), Alfonso X, el Sabio, Murcia, 2009b, pp. 130-131; D. ORTIZ DE ZÚÑIGA, op. cit., 1795, T. IV, pp. 83-84; y A. MORALES MARTÍNEZ, "Rey y santo. Ceremonial por Fernando III en la catedral de Sevilla", V. MÍNGUEZ (dir), Visiones de la monarquía hispánica, Castellón de la Plana, 2007, pp. 95-100.

37 Crónicas de los reyes de Castilla, 1953, T. I, 8; M. GONZALEZ JIMÉNEZ, op. cit., doc. 186, 211. I. MONTES ROMERO-CAMACHO, "El nacimiento del cabildo catedral de Sevilla en el siglo XIII", Archivo Hispalense, 234-236 (1994), pp. 430-431; T. LAGUNA PAÚL, op. cit., 2001b, pp. 240-242; y "Si el nuestro cuerpo fuese enterrado en Sevilla': Alfonso X y la capilla de los Reyes", I.G. BANGO (coord.), Alfonso X el sabio, Murcia, 2009c, pp. 119-122.

38 T. LAGUNA PAÚL, op. cit., 2012, pp. 186-188. J. ARIAS NEVADO, "El papel de los emblemas heráldicos en la ceremonias funerarias de la Edad Media (siglos XIII-XVI)", En la España Medieval, 29/extra (2006), pp. 49-80. O. PÉREZ MONZÓN, "Quando rey perdemos nun[u]ua bien nos fallamos. La muerte del rey en Castilla en el siglo XIII", Archivo Español de Arte, 320 (2007), p. 384. 
occidental que lo mantuvieron ausente de Sevilla durante diez años y marcó su huella en las cantigas 257 y $324^{39}$. La primera explica que el monarca preparó al detalle todos los aspectos de su partida guardando personalmente sus relicarios en el Alcázar de Sevilla, pero al volver comprobó que, a pesar de las precauciones, sólo permanecieron en buen estado las reliquias de la Virgen; el incidente quizás esté relacionado con la factura del tríptico relicario que ingresó en la catedral de Sevilla después de su muerte ${ }^{40}$. La segunda menciona cómo el Rey Sabio, después de asistir a una celebración de la Natividad de la Virgen en la Catedral de Sevilla -"na grand'eigreja da See"- regaló, a petición popular, una imagen de la Virgen forrada con láminas de plata para que presidiera, a partir de entonces, los cultos en el altar mayor de este templo. La demanda justifica la cesión alfonsí de la Virgen de la Sede y la voluntad de tener, de venerar, en este ámbito otra imagen directamente vinculada con la monarquía, ya que la de Santa María de Fernando III había sido trasladada al altar de la capilla de los reyes antes de su vuelta, a mediados de $1279^{41}$.

La reorganización de ambas capillas implicó cambios en el desarrollo de algunos protocolos del aniversario de Fernando III y de la conmemoración del 23 de noviembre y, además, el rezo de la sabatina fue trasladado al altar de la Virgen donde estaban enterrados los Reyes. En la conmemoración de la conquista, el rito incorporó la estación a la capilla funeraria con el fin de tomar, después del rezo de tercias, el pendón y la espada de Fernando III necesarios para trasladarlas al altar mayor y llevar a cabo la procesión y la celebración litúrgica ${ }^{42}$.

El texto de la cantiga 292 (fig. 6), redactado después de la llegada del féretro de la reina Beatriz a Sevilla en 1279, tiene un valor documental importantísimo para conocer algunas características de la Capilla de los Reyes para todos los investigadores que, desde Ricardo del Arco y Martínez de Aguirre, interpretamos su información completándola con una descripción de 1345 y los escasos restos conservados. La cantiga identifica perfectamente a la Virgen de los Reyes con la interlocutora de Fernando III y expone la sacralización del espacio llevada a cabo que, indudablemente, otorgaba verosimilitud a los relatos miniados y conducía a los fieles, a los espectadores, a ver para creer $^{43}$.

39 T. LAGUNA PAÚL, op. cit., 2001b, pp. 241-242; y op. cit., 2012, pp. 187-188; R. SÁNCHEZ AMEIJEIRAS, op. cit., 2002, pp. 260-262.

40 D. ORTIZ DE ZÚÑIGA, op. cit., 1795, T. IV, pp. 83-84; T. LAGUNA PAÚL, op. cit., 2009c, pp. 120; y “Tablas alfonsíes" I.G. BANGO (coord.), Alfonso X el sabio, Murcia, 2009d, pp. 638-639; M.L. MARTíN ANSÓN, "El culto a las reliquias en las Cantigas de Santa María de Alfonso X el Sabio", Espacio, Tiempo y Forma. Serie III. Historia Medieval, 24 (2011), pp. 215-216.

41 J. GESTOSO Y PÉREZ, op. cit., 1890, T.II, p. 190; J. HERNÁNDEZ DÍAZ, "Estudio de la iconografía mariana hispalense de la época fernandina", Archivo Hispalense, 27-32, pp. 13-18; J. MARTÍNEZ DE AGUIRRE, "La introducción de la escultura gótica en Sevilla (1248-1300)", A. MORALES (coord.), Metropolis Totius Hispaniae, Sevilla, 1998, pp. 129-130; T. LAGUNA PAÚL, op. cit., 2001b; y "Virgen de la Sede”, I. BANGO (coord.), en Las maravillas de la España medieval, León, 2001c, pp. 241 y 436.; op. cit., 2009c, pp. 120.

42 T. LAGUNA PAÚL, op. cit., 2012, pp. 189-190.

43 El Tratado de autómatas de la Biblioteca Mediceo-Laurenciana (ms. Or. 133) es el único texto árabe copiado en la corte de Alfonso X que ha llegado hasta nosotros. A. DOMÍNGUEZ RODRÍGUEZ, "Algunas precisiones sobre el arte alfonsí", Cantigas de Santa Maria, Edición facsímil del códice BR20 de la Biblioteca Nazionale Centrale de Florencia, Madrid, 1989, pp. 149-151; J. YARZA LUACES, "Historias milagrosas de la 
La cantiga menciona expresamente las sepulturas blasonadas de sus padres, la presencia de una figura de Fernando III entronizado que sostenía en la mano derecha una espada desenvainada y lucía un maravilloso anillo realizado por maestre Jorge, orfebre de Toledo y artífice de otros encargos efectuados por Alfonso X para el mismo recinto. Esta estatua constituyó uno de los elementos más novedosos de todo el conjunto funerario, que sorprendió a los contemporáneos y posiblemente, como señaló Rocío Sánchez Ameijeiras, pudo ser el motor argumental de este texto donde el rey sabio justificó todos cambios y planteamientos, el carácter ideológico y artístico de la empresa haciendo al mismo platero protagonista de un suceso milagroso. En una aparición post mortem, Fernando III le ordena ir desde Toledo a Sevilla para ofrecer y colocar su anillo a la Virgen y, además, comunicar a su hijo, el Rey Alfonso, su disconformidad con la posición de su escultura y la necesitad de trasladar a la Señora a donde estaba su propia estatua para ser colocado de rodillas y servir a Quienes les debía su reino ${ }^{44}$. Alfonso $\mathrm{X}$ encargó unas tumbas con yacentes que fueron desechadas al proceder a los traslados y constatar el buen estado de conservación de sus cuerpos; con este hecho habitual en otras narraciones hagiográficas el monarca argumentó la confección de los sepulcros monumentales con decoraciones heráldicas en plata, sin yacentes, que enaltecían el linaje y personalizaban los restos ${ }^{45}$.

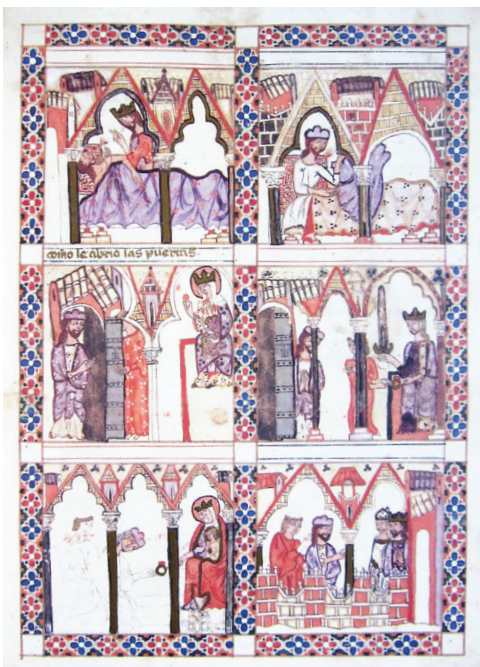

Fig. 6. Cantiga 292. Códice de Florencia; Florencia, Biblioteca Nazionale Centrale ms. B.R.20, fol. 12r. Reproducción de la edición de Edilán, 1989.

\footnotetext{
Virgen en el siglo XIII", Lambard, 15 (2002-2003), pp. 210-237; A. GARCÍA AVILÉS, "Imágenes vivientes; idolatría y herejía en la miniatura de Alfonso X el sabio", Goya, 321 (2007), pp. 324-336; T. LAGUNA PAÚL, op. cit., 2009a, pp. 435;y op. cit., 2009c, pp. 225-231; L. FERNÁNDEZ FERNÁNDEZ, "Muy noble, et mucho alto et mucho Honrado. La construcción de la imagen de Fernando III", C. DE AYALA y M. RIOS (coord.), Fernando III tiempo de cruzada, Madrid, 2012, pp. 147-148.

44 Biblioteca Nazionale Centrale Florencia, ms. B.R.20, fols. 10v-11v. Escorial, ms. B.I.2 fol. 261r-262; R. SÁNCHEZ AMEIJEIRAS, op. cit., 2002, pp. 262-263; y T. LAGUNA PAÚL, op. cit., 2012, pp. 191-196.

45 T. LAGUNA PAÚL, op. cit., 2012, pp. 193-194.
} 
La estatua de Fernando III sería un maniquí de tamaño natural, semejante a los confeccionados para las exequias fúnebres en la abadía de Westminster, que fue representado en la Procesión de la consagración de la iglesia del Sagrario y las fiestas por el Breve del papa Alejandro VII favorable a la Inmaculada Concepción en 1662, y describió Diego Ortiz de Zúñiga nueve años después (fig. 12) ${ }^{46}$. Sus antecedentes se han buscado en el emperador Federico $\mathrm{II}^{47}$ y en la leyenda del hallazgo del cuerpo incorrupto y entronizado de Carlomagno en Aquisgrán, que Beatriz Stauffen transmitió a sus hijos. Su abuelo, el emperador Federico I Barbarroja, promovió en 1165 el traslado del cuerpo de Carlomagno y su canonización y los restos fueron depositados por su tío Federico II en una urna de oro en 1215. La canonización tuvo amplia trascendencia y en Castilla encontró su huella en la leyenda del Cid Campeador, que difunto y atado a su caballo ganó la última batalla y después fue trasladado a Cardeña donde estuvo insepulto ante el altar de la iglesia. Los monjes del monasterio burgalés promovieron esta tradición que Alfonso X incorporó a la Primera Crónica General y encargó la reorganización del sepulcro con un monumento en la década de $1270^{48}$.

El texto señala también la suntuosidad de la Capilla de los Reyes y los trabajos encargados por el rey sabio al orfebre Jorge de Toledo focalizándolos, narrativamente, en el rechazo del santo rey por su ostentoso anillo y su deseo de ofrecerlo a la Virgen. Cristiano ejemplar, héroe invencible y soberano cabal, además, protesta del lugar donde está colocado en la capilla, desea ocupar un plano inferior a la Virgen y permanecer arrodillado, como un servidor, porque no es justo estar a su mismo nivel. Se desconoce si cumplieron todos los deseos ya que las fuentes posteriores describen a la Virgen presidiendo la capilla en su altar dentro de un tabernáculo y en el lado del evangelio, a Fernando III en majestad acompañado por las figuras de su mujer e hijo en un plano mas bajo, enfrente de sus sepulcros. El texto alfonsí omite la escultura de la reina Beatriz, pero la mención expresa al traslado de sus restos y ataúd desde las Huelgas a Sevilla señala una fecha límite para la terminación de la capilla en noviembre 1279. Los trabajos comenzarían antes, cuando realizaron el llamado repartimiento de la catedral mudéjar que diferenció topográfica y cultualmente los espacios de la corona y del cabildo, según una documentación perdida que consultó Espinosa de los Monteros en el siglo XVII ${ }^{49}$.

Esta reorganización fue un auténtico reparto de las naves centrales que dejó su huella en el contenido de los privilegios concedidos desde 1261 y durante la década que Alfonso X se ausentó de Sevilla. Pese a la distancia, el monumento de Fernando

46 D. ORTIZ DE ZÚÑIGA, op. cit., 1795, T. IV, 97-98; T. LAGUNA PAÚL, op. cit., 2009c, p. 124; у op. cit., 2012, pp. 210-211.

47 J. MARTÍNEZ DE AGUIRRE, op. cit., 1998, pp. 120-121, cita como precedentes el retrato de Federico II en la Porta Romana de Capua hacia 1234 y el de Carlos de Anjou, rey de Sicilia, hacia 1276; T. LAGUNA PAÚL, op. cit., 1998, p. 61; op. cit., 2001b, p. 245.

48 R. SÁNCHEZ AMEIJEIRAS, op. cit., 2002, pp. 262-263 ; R. ALONSO ÁLVAREZ, op. cit., 2003, pp. 472-479, 481; y op. cit., 2007, pp. 6-7; M. DIAGO HERNANDO, "La pervivencia histórica del mito: los casos de Carlomagno y Federico Barbarroja", Memoria, mito y realidad en la España medieval: III semana de estudios medievales, Nájera, 2003, pp. 237-246.

49 P. ESPINOSA DE LOS MONTEROS, Teatro de la santa Iglesia metropolitana de Sevilla, Primada antigua de las Españas, Sevilla, 1635, pp. 33-34; A. JIMÉNEZ, I. PÉREZ, cartografía de la Montaña Hueca, Sevilla, 1997, pp. 22-27; T. LAGUNA PAÚL, op.cit., 1998, pp. 52-97; y op. cit., 2001b, pp. 241-242. 
III se terminó antes de 1270 y las obras del panteón estarían muy avanzadas el 5 de noviembre de 1271 cuando, en Murcia, concedió privilegios al cabildo de clérigos parroquiales de Sevilla comprometiéndoles a participar en los aniversarios de sus antepasados y en las conmemoraciones a realizar en sus capillas reales. Las titulaciones de éstas manifiestan las devociones privadas del monarca, reiteradas en otros privilegios concedidos en 1279 a los clérigos parroquiales de Córdoba y en 1283 a los de Jérez y Sanlucar de Barrameda ${ }^{50}$.

Alfonso X señaló dos lugares donde realizar los cinco aniversarios anuales por sus predecesores: los clérigos acudirían a la "Iglesia de Sancta María" -la catedral- para el aniversario del rey don Fernando y los otros cuatro por sus abuelos se celebrarían en "nuestra capiella de Santa Elysabeth". Esta última estaba en el Alcázar cerca del llamado posteriormente cuarto del Almirante, aunque la titulación no excluye que en la capilla de los Reyes existiera algún altar con esta advocación ya que la reina Violante de Aragón era sobrina de la santa, canonizada en 1235, y fue precisamente su madre la introductora de esta devoción en la Península Ibérica ${ }^{51}$. Estos lazos familiares, que enaltecieron el matrimonio del rey sabio con la princesa aragonesa, pudieron plasmarse de alguna forma en el proyecto alfonsí de la capilla, por la trascendencia que tuvo para la imagen del poder castellano-leonés entroncar con una estirpe de santidad. Como señuelo de esta devoción se ha destacado el Officium et vita S. Elisabeth landgraviae Thuringiae (B.N.F. n.a.l. 868), cuya factura e ilustración inacabada denota la colaboración de algunos artífices relacionados con las Cantigas (Escorial ms.b.I.2 y T.I.1 $)^{52}$. Estos cultos estaban perfectamente diferenciados de los comprometidos por el monarca en otras de sus capillas sevillanas: la capilla de la Torre del Oro donde decían misa el día de San Ildefonso, la del Arenal en las Atarazanas bajo la advocación de San Jorge donde realizaban cultos el día de San Nicolás, y la de San Clemente localizada también en el Alcázar donde celebraban otra misa al concluir la procesión y las ceremonias del 23 de noviembre en la catedral.

A la muerte de Alfonso X, en abril de 1284, la Iglesia de Sevilla recibió sus últimas donaciones destinadas a realzar las ceremonias religiosas del altar mayor de la catedral y consolidar el ajuar litúrgico de la capilla de los Reyes: ornamentos, libros y esculturas de devoción de su capilla privada, un complemento indispensable de la escenografía sacra que, seguramente, habían utilizado en numerosas ocasiones en los cultos de su capilla hispalense. A la catedral donó el tríptico relicario de plata, las Tablas, para llevarlas en procesión y venerarlas en el altar mayor en las grandes fiestas dedicadas a la Virgen, y a la capilla Real un tríptico de marfil grande con escenas de la vida de la Virgen para colocarlo todos los sábados en "el altar de Sanc-

50 M. GONZALEZ JIMÉNEZ, Diplomatario, 1991, doc. 387, 447 y 516

51 T. LAGUNA PAÚL, op. cit., 2012, pp. 196-197. Debo y agradezco la localización de la capilla de Santa Isabel a Doña Isabel González Ferrín. La capilla del Alcázar dedicada a San Jorge estaba localizada en la octava nave de las Atarazanas según la noticia proporcionada por Pablo E. Pérez-Malláina y en 1478 hicieron obras en sus bóvedas: vid. M. FERNÁNDEZ GÓMEZ, (ed.), El Alcázar y las Atarazanas de Sevilla en el Reinado de los Reyes Católicos. Las cuentas del obrero mayor Francisco de Madrid, Sevilla, 2011, pp. 46, 69.

52 F. AVRIL, et alli, Manuscrits enluminés de la Péninsule Ibérique, Paris, 1982, nº 94 ; T. LAGUNA PAÚL, op. cit., 2009c, p. 129; J. PLANAS BADENAS, “Códices miniados en los reinos cristianos de la península Ibérica durante el siglo XIII”, I.G. BANGO (coord.), Alfonso X el sabio, Murcia, 2009, pp. $274-275$. 
ta María" -capilla de los Reyes-, que sería una obra francesa de aproximadamente cincuenta centímetros de altura, mencionada en 1362 en el testamento de Pedro I ${ }^{53}$. Algunos ornamentos aún existían a comienzos del siglo XVI y fueron equiparables a los textiles miniados en las viñetas de las Cantigas y a los conservados en el Panteón real de las Huelgas ${ }^{54}$. Entre los libros para el servicio de altar había un Evangeliario, confeccionado en 1260 encuadernado con tablas de cuero leonado, un Epistolario y un Sacramentario, conservados ambos en el fondo de la Biblioteca Capitular ${ }^{55}$. Estos volúmenes están diferenciados de las biblias, de los cuatro volúmenes del Espejo Historial y de "todos los libros de los Cantares de loor de Santa María", para los que dispuso su ingreso en el templo donde lo enterraran pero dio la posibilidad a sus sucesores de recuperarlos a cambio de alguna contraprestación, como evidentemente ocurrió con el Códice Rico (RBME T-I-1) y el de Florencia (B.N.C.F. ms. B.R.20). El Códice de los músicos (RBME b-I-2) permaneció en la catedral de Sevilla hasta su traslado al Escorial en el siglo XVI ${ }^{56}$.

Durante los reinados de su hijo Sancho IV y su nieto Alfonso XI se afianzó definitivamente el programa ideológico e iconográfico de esta capilla, se consolidó el ceremonial regio, se perfeccionó el recinto funerario reforzando la imagen del poder real flanqueando el simulacro del rey santo con el de la reina Beatriz y su hijo el Rey Sabio, cobró auge la veneración a las reliquias de Fernando III y se promovió una campaña para concluir las miniaturas del códice de Florencia ilustrándose, entre otras, las cantigas 292 y 256 que atañen directamente a los progenitores de Alfonso X y a las imágenes marianas vinculadas con la catedral de Sevilla ${ }^{57}$. El iluminador de la cantiga 292 recreó la catedral mudéjar y la capilla de los Reyes con gran ingenuidad, destacó unos arcos polilobulados en el altar de la Virgen y la escultura sedente de Fernando III con su espada de valor taumatúrgico, que reproduce las características percibidas por los fieles y súbditos: el gran rubí del pomo, descrito en 1345, formado por dos piedras de cristal de roca lacadas interiormente con sangre de drago y cardenillo (fig.7). Esta espada incorporada al ritual de la conmemoración de la conquista

53 T. LAGUNA PAÚL, op. cit., 2012, p. 198.

54 T. LAGUNA PAÚL, op. cit., 1998, pp. 230-231; у op. cit., 2001, pp. 198-199; у op. cit., 2009c, pp. 220, 236-237. Para los textiles del s. XIII: Vestiduras ricas: el Monasterio de las Huelgas y si época, 1170-1340, Madrid, 2005; L. RODRÍGUEZ PEINADO, "El arte textil en el siglo XIII. Cubrir, adornar y representar: una expresión de lujo y color", L. FERNÁNDEZ FERNÁNDEZ y J.C. RUIZ SOUZA (coords.), Alfonso X el sabio. Las cantigas de Santa María, códice Rico ms. T-I-1, Madrid, 2011, pp. 349-358.

55 T. LAGUNA PAÚL, "Epistolario", A. MORALES (coord.), Metropolis Totius Hispaniae, Sevilla, 1998b, pp. 230-231; y op. cit., 2009c, pp. 128-129.

56 E. RUIZ GARCÍA, El imaginario de una reina. Páginas selectas del patrimonio escrito de Isabel la Católica, Madrid, 2007, pp. 155-159; L. FERNÁNDEZ FERNÁNDEZ, "Historia florentina del códice de las Cantigas de Santa María. Ms. B.R.2 de la Biblioteca Palatina a la Nazionale Centrale”, Reales Sitios, 164 (2005), pp. 18-29.

57 F. GUTIÉRREZ BAÑOS, Las empresas artísticas de Sancho IV, Burgos, 1997, pp. 143-163, 150152, 156-157,195-199; T. LAGUNA PAÚL, op. cit., 2001b, pp. 243-245; у op. cit., 2012, pp. 199-201; R. SÁNCHEZ AMEIJERIRAS, op. cit., 2002, pp. 264-268; y "Cultura visual en tiempos de María de Molina: poder, devoción y doctrina”, M. C. SEVILLANO (coord.), El conocimiento del pasado, una herramienta para la igualdad, 2005, pp. 295-273; L. FERNÁNDEZ FERNÁNDEZ, "Las cantigas de santa María. Fortuna crítica de sus manuscritos", Alcanate, VI (2008-2009), pp. 345-346. 
al menos desde el 23 de noviembre de 1253, era un auténtico relicario, objeto de veneración precultual, protectora y talismán para quien la portara ${ }^{58}$.

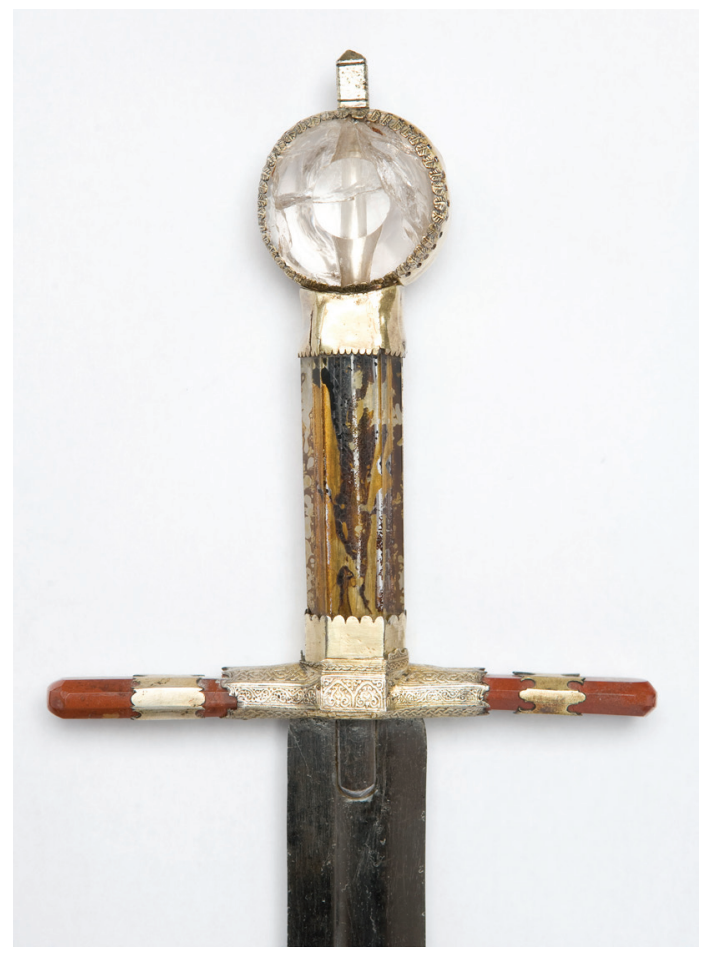

Fig. 7. Detalle del pomo y arriaz de la espada de Fernando III, que tomaban del simulacro de la capilla de los Reyes. Catedral de Sevilla, capilla Real, INV 410910111469.000.

La disposición espacial de la capilla de los Reyes (fig.9), sus esculturas, sepulcros y ajuar marcaban una escenografía de fuerte impacto visual para los fieles y súbditos que acudían a la catedral de Sevilla para participar en los aniversarios anuales donde concurrían cristianos, judíos y árabes o, sencillamente para orar. Su organización se conoce gracias a una descripción que copió Hernán Pérez de Guzmán en 1345, publicó Ortiz de Zúñiga en 1677 y, reeditada en varias ocasiones, constituye la mejor explicación del ámbito cultual alfonsí que tenía entonces varios elementos incorporados por Sancho IV y Alfonso XI para reforzar la imagen pública de los soberanos ${ }^{59}$

58 I. HERRÁEZ MARTÍN, "La espada de Fernando III, el santo”, Laboratorio de Arte, 15 (2002), p. 339; T. LAGUNA PAÚL, "Espada de Fernando III”, Alfonso IX y su época, Fdo. LOPEZ ALSINA (coord.), Coruña, 2008, pp. 130-132; T. LAGUNA PAÚL, op. cit., 2009c; y op.cit., 2009b, pp. 222-224 y 130-131; y op. cit., 2012, pp. 191-196 у 200-201; L. FERNÁNDEZ FERNÁNDEZop. cit., 2005, pp. 18-29; y op. cit., 2008/2009, pp. 322-348; y op. cit., 2012, pp. 155-157, 163-166.

59 D. ORTIZ DE ZÚÑIGA, op. cit., 1795, T. II, 143-145; A. JIMÉNEZ MARTÍN, op. cit., 2006, pp 34-35. 


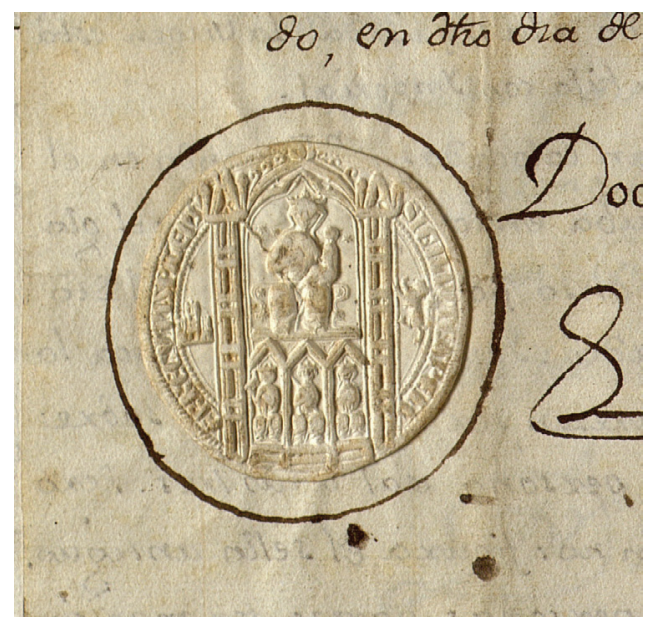

Fig. 8. Sello placa del siglo XIV inserto en el acta del 17-9-1783. Catedral de Sevilla, Archivo de la capilla Real, Sec. 1, serie 1, libro 15, fol. 253v (C) Catedral de Sevilla, Biblioteca Capitular y Colombina.

Esta escenografía sacra quedó sintetizada visualmente en los sellos medievales que muestran perfectamente el ámbito cultual con la Virgen de los Reyes, la imagen del poder con los simulacros y las gradas de acceso al conjunto que constituyeron los elementos representativos e innovadores, mantenidos en la instalación de la capilla Real después de 1433. Los menciona la cédula de Felipe II de 1578 y su recuerdo perduró en el sello barroco aprobado el 26 de septiembre de $1783^{60}$. A mediados del siglo XIV esta capilla fue, sin duda, la expresión artística de la memoria de Fernando III gestada por Alfonso X, del poder mayestático de los soberanos castellano-leoneses ante la Virgen, de su obligación por velar de las necesidades de sus súbditos y vasallos, del ideario de Sancho IV y de la revitalización dinástica llevada a cabo por Alfonso XI.

La capilla tenía una superficie cercana a $440 \mathrm{~m}^{2}$ y su perímetro exterior acotó con rejas ocho naves de anchura y siete de profundidad en la mitad oriental de la catedral mudéjar. La altura de las naves de la mezquita, con sus artesonados situados aproximadamente a catorce metros, permitió construir una plataforma abovedada de dos metros y medio o tres de altura, semejante a la realizada después en la catedral de Córdoba, sobre la que se dispuso el ámbito ceremonial y regio mientras el espacio inferior pudo destinarse a cementerio real y a otras necesidades funcionales ${ }^{61}$ (fig.9). Las lámparas, que iluminaban constantemente el recinto, facilitaban la visión a los fieles que, desde las naves de la catedral, percibirían perfectamente los tres sepulcros

60 D. ORTIZ DE ZÚÑIGA, D., op. cit., 1795, T. IV, pp. 83-84; A.C.S., Sec. Capilla Real, Sec. 1, serie 1, libro 15, fol. 252v-253v; M.J. SANZ SERRANO, "La imagen medieval del antiguo tabernáculo de plata de la capilla Real de Sevilla, a través de los sellos medievales", Laboratorio de Arte, 11 (1998), pp. 56-59; T. LAGUNA PAÚL, "Mobiliario medieval de la capilla de los Reyes de la catedral de Sevilla. Aportaciones a los 'Ornamenta ecclesiae' de su etapa fundacional', Laboratorio de Arte, 25, (2013), p. 59.

61 T. LAGUNA PAÚL, op. cit., 2012, pp. 201-203. 


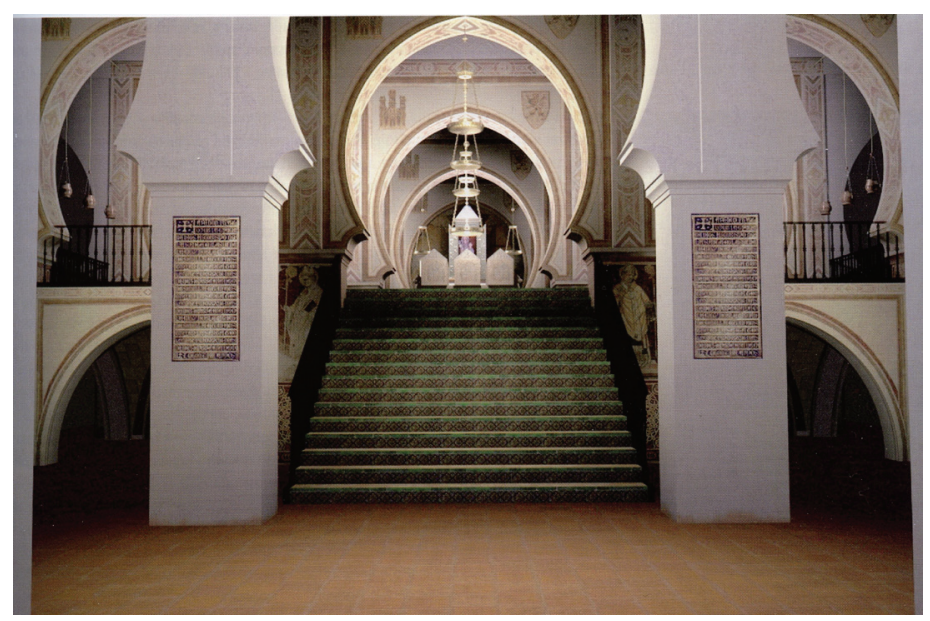

Fig. 9. Reconstrucción del acceso a la capilla de los Reyes realizada por A. Almagro Gorbea en 2009. (C) A. Almagro.

reales, situados delante del altar con la Virgen en sus tabernáculos de plata y los simulacros de los reyes que, sentados en el lado del evangelio dentro de un sitial triple de plata, la antigua sedilia litúrgica readaptada en el siglo XIV, recibían un homenaje constante, con independencia del ceremonial desarrollado el día de san Clemente y en el aniversario de Fernando III. Los sepulcros sin yacente y las efigies de los monarcas, sedentes y de tamaño natural, manifestaban visualmente las normas del Espéculo que señalan cómo en ausencia del monarca su imagen debe recibir el mismo homenaje y reconocimiento. Eran la representación estática y tridimensional legislada en las Partidas porque los súbditos desde las naves veían a los monarcas, ataviados con sus mejores ropas, como "vicarios de Dios en cada uno de sus reinos" que fueron "puestos en la tierra en lugar de Dios para cumplir justicia" ${ }^{2}$. Los simulacros no eran únicamente sólo una presencia post mortem porque formaron parte del ceremonial de la realeza, tuvieron el mismo protocolo que los soberanos en vida y en 1407 el infante Don Fernando de Antequera les rindió el mismo pleito homenaje que hacían, habitualmente, los peregrinos delante del monumento de Alfonso VIII en las Huelgas de Burgos ${ }^{63}$. Este recinto tendría, seguramente, pinturas murales cubriendo sus

62 ALFONSO X, Partidas, Partida II Tit. I Ley IV y V (ed. Madrid 1872, pp. 324 y 325); T. LAGUNA PAÚL, op. cit., 1998, p. 60; y "Mobiliario medieval de la capilla de los Reyes de la Catedral de Sevilla", Laboratorio de Arte, 25 (2103), pp. 53-77.

63 J.M. CARRIAZO ARROQUIA, Anecdotario sevillano del siglo XV (Crónica de Juan II de Castilla por Alvar García de Santa María), Sevilla, 1947, pp. 44-47: “e después que fueron tirados todos los brocales, tomó la espada e púsola en la mano del rey don Fernando. E besóle el pie e la mano, e al rey don Alfonso la mano, e a la Reina la mano"; J. MARTÍNEZ DE AGUIRRE, op. cit., 1995, p. 116; T. LAGUNA PAÚL, op. cit., 2001b, p. 244; O. PÉREZ MONZÓN, op. cit., 2007, pp. 383-384; y “Heráldica versus imagen”, I.G.. BANGO (coord.), Alfonso X, el sabio, Murcia, 2009, pp. 94-101. 
pilares y en las bóvedas de la plataforma baja inscripciones pintadas que rodearían el perímetro del artesonado, la cubierta superior, el intradós y estados de los arcos cuya iconografía comprendería representaciones de los emblemas de la corona castellanoleonesa, textos conmemorativos y citas bíblicas como, por ejemplo, la del libro de los Proverbios que enmarca el dosel barroco de la Virgen de los Reyes: "Per me Reges regnant, et legum conditores iusta descenderunt" ${ }^{64}$.

La capilla adaptó un espacio mudéjar a las necesidades cultuales y al ceremonial de la corona, configurando un lugar de exaltación mariana que reforzaba la imagen de la monarquía castellano-leonesa y que exigía la veneración constante a Fernando III, cuyo monumento de mármol tenía volúmenes sencillos con epitafios en castellano, latín, árabe y hebreo que responden a la obsesión alfonsí por documentar el óbito paterno en todas las eras y cronologías conocidas. Del sepulcro, que perdió su composición originaria en los traslados de la capilla de los Reyes en 1433 y 1579, se conservan las inscripciones talladas y separadas por una franja heráldica en dos piezas de mármol que corresponderían a las partes longitudinales de la sepultura $\mathrm{y}$, ahora, forman parte del basamento donde descansa la urna de plata encargada después de la canonización a Juan Laureano de Pina (Fig. 10). En origen sería una urna de mármol, apoyada en torsos de leones, con la tapa plana o con derrames y sus inscripciones doradas con los emblemas heráldicos realzados en color, manteniendo los códigos de los blasones, y flanqueadas por otras placas de mármol con las armas de Castilla y León que debieron repetirse en los frentes, al igual que otros conservados en las Huelgas de Burgos ${ }^{65}$. Su volumetría recordaría al sepulcro encargado por Sancho IV para los restos de Alfonso VI en Sahagún (1286) o el que dispuso para su enterramiento en Toledo representado en su testamento de $1285^{66}$. La realización del sepulcro-monumento por parte de Alfonso X puede fijarse entre 1261 y 1270, según la mención realizada por Fray Juan Gil de Zamora y en el interior colocaron el ataúd de madera forrado con ricas telas y guarnecido con una cruz de filigrana mudéjar. El cuerpo del santo rey fue amortajado con una camisa de lino bordada con cruces rojas y azules, paños y ropas esculturadas con castillos y leones, una cofia bordada donde apoyaba la corona de oro, zapatos de cordobán y unas espuelas de plata compañeras de la espada que todavía le acompaña ${ }^{67}$. Los textos anteriores a mediados del siglo XVI omiten cualquier referencia a la Virgen de las Batallas, la Socia Belli, la imagen

\footnotetext{
64 T. LAGUNA PAÚL, op. cit., 2009c, p. 129.

65 T. LAGUNA PAÚL, op. cit., 2012, pp. 211-213. Las planchas miden $57 \mathrm{~cm}$. de altura y $133 \mathrm{~cm}$. / 144 $\mathrm{cm}$. de longitud, el grosor oscila entre 3 y $4 \mathrm{~cm}$.

66 J. MARTÍNEZ DE AGUIRRE, op. cit., 1995, p. 115; F. GUTIÉRREZ BAÑOS, op. cit., 1997, pp. 157163 y $209-214$.

67 Las dos cajas estaban en mal estado en el siglo XVI y han cambiado varias veces el tejido exterior; la longitud de la caja de albardilla con la cruz de plata $(43 \times 185 \times 47 \mathrm{~cm})$ es, aproximadamente, diez centímetros más corta que la caja lisa donde depositaban la anterior $(52 \times 192 \times 50 \mathrm{~cm})$, al menos, desde que se efectuaron los traslados en 1562 hasta la confección de la actual de plata concluida en 1729. Para el ajuar: M. GÓMEZ MORENO, "Preseas reales sevillanas", Archivo Hispalense, IX (1948), pp. 191-204; M.J. SANZ SERRANO, "Ajuares funerarios de Fernando III, Beatriz de Suabia y Alfonso X", M. GONZÁLEZ JIMÉNEZ (Coord.), Sevilla 1248. Congreso Internacional Conmemorativo del 750 aniversario de la conquista de Sevilla por Fernando III, Rey de Castilla y de León, Madrid, 2000, pp. 432-440; T. LAGUNA PAÚL, op. cit., 2009a, p. 236.
} 
de marfil (fig. 14) que, según tradiciones, le acompañó durante gran parte de su vida $\mathrm{y}$ en la sepultura ${ }^{68}$.

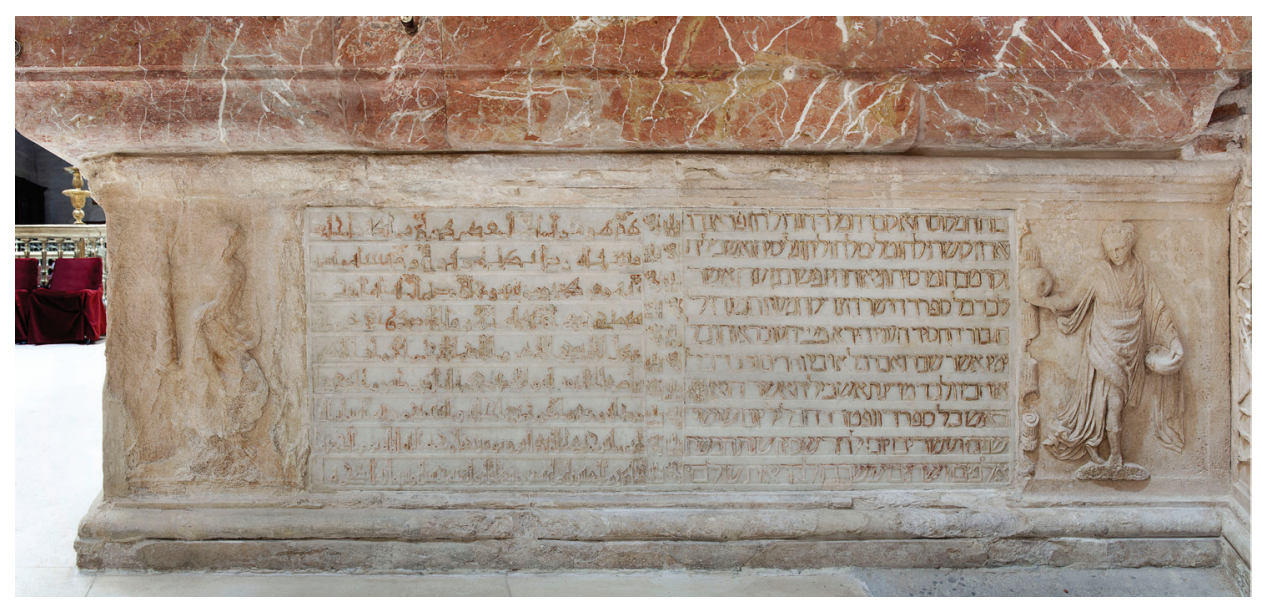

Fig. 10. Inscripción árabe y hebrea del monumento de Fernando III (h. 1261-1279), insertos en la base del altar del santo. Catedral de Sevilla, capilla Real. (C) Catedral de Sevilla y Artyco, 2012.

El simulacro de Fernando III y el sepulcro de mármol formaron una unidad, eran el monumento que Alfonso X concibió para conmemorar la memoria de su padre y la imagen pública de esta capilla, porque la tumba carecía de yacente. El ceremonial exigió una representación tridimensional con una recreación literaria de la figura del monarca:

“AQI: IAZE : EL : REY : MUY : ONDRADO : DO : F/ERRĀDO : SENOR : DE : CASTIELLA : E : DE LEO : DE GALLIZIA : DE SEVILLA : DE C/ORDOVA : DE MVRCIA : ET: DEIAHEN : EL : Q : CON/QISO : TODA : ESPAÑA : EL : MAS : LEAL : E : EL : MAS : /VDADERO : E : EL : MAS : FRANC : E : EL : MAS : SOFRIDO : EEL : MAS : APVESTO : E : EL : MAS : GRANA/DO : E : EL : MAS : SOFRIDO : EEL : MASS : OMYLDOSO/EEL : QMAS : TEMIE : ADIOSE : ELQ : MAS : FAZ/IA : SERVICIO : EEL : QQEBRANTO : EDESTRVIO : A : TO/DOS : SVSENEMIGOS : E : EL : QVE : ALCO : E ONDRO : /ATODOS : SVS : AMIGOS : E : COQISO : LACIBD/AT : DE : SEVILLAQ : ES : CABECA : DE : TODA : ES/ PAÑA : E : PASSOS : HI : ENEL : POSTREMERO : DIADE : M/AYO : EN : LA : ERA : DE MILL : ET : CC : NOVAETA AÑOS" ${ }^{69}$.

68 T. LAGUNA PAÚL, "Virgen de las Batallas", I.G. BANGO (coord.), Las Maravillas de la España Medieval, León, 2001d, p.250. C. YVARD (dir.), Gothic Ivoires. The Courtauld Institute of Art. En línea [http://www.gothicivories.courtauld.ac.uk/search/results.html?ixsid=1_UGIePCNCn\&qs=sevilla], consultado el 20-04-2013.

69 Cito la transcripción de A. JIMÉNEZ MARTÍN, "Las fechas de las formas", AA.VV, La catedral de Sevilla. Fundación y fábrica de la obra nueva, Sevilla, 2006, p. 26. 
Los sepulcros reales y el altar de la Virgen formaban una composición ascendente, con un plano celestial y otro intermedio o regio donde los monarcas en actitud mayestática, sentados bajo un sitial triple, la antigua sedilia litúrgica, velaban las cajas de sus restos mortales y eran la escenografía tridimensional de la imagen del poder en la tierra. La elevación de la capilla mostraba a los soberanos muy cerca de la Reina del cielo y los fieles observaban las ceremonias desde las naves, presididas por la Virgen, resplandeciente en el interior de unos tabernáculos extraordinarios, sumariamente representados en los sellos medievales, cuyos batientes abiertos realzaban su presencia en los momentos de culto u ocultarla para destacar la atención en el espacio funerario. Cuando el tabernáculo estuviera cerrado y la Virgen oculta en la penumbra de la capilla los reyes con sus sepulcros serían, prácticamente, los únicos elementos visibles, los protagonistas de un espacio parateatral donde la corte regia es como es, porque Dios de este modo lo ha ordenado ${ }^{70}$ (figs. 3, 8 y 9).

La Virgen de los Reyes presidía el altar dentro de un chapitel argénteo, apoyado en cuatro columnas con batientes de madera chapada del mismo metal, guardado dentro de otro tabernáculo de plata de mayor tamaño, provisto de puertas de madera pintadas, cuya doble estructura se constata en otros altares contemporáneos y, especialmente, en las pinturas murales de la capilla de san Martín de la catedral de Salamanca, realizadas por Antón Sánchez de Segovia en 1262. La imagen y los simulacros reales estaban sentados en sillas de madera chapadas con castillos y leones, que tenían los brazales con pomos redondos, las cadiras representadas en los códices de las cantigas y en el Libro de los juegos. El chapitel argénteo del tabernáculo interior tenía las mismas decoraciones heráldicas y unos batientes guarnecidos con cientos de piedras de formando alineaciones cromáticas alternantes verdes, moradas y azules, que brillaban cuando lo descubrían. Exteriormente estaban chapados con treinta y seis planchas de plata, decoradas con las armas de Castilla y León, semejantes a las que cubrían su bóveda interna donde encajaban otras piedras de mayor tamaño. Los frentes estaban chapados con placas heráldicas y tenía una torre en cada esquina, apoyada en cuatro pilares de plata que remataba con un florón. Este tabernáculo interior abierto formaba alrededor de la imagen una aureola brillante que simbolizaba el entorno celestial de la Señora y, seguramente, a su riqueza alude la cantiga 292 cuando menciona unas "portas d'our e non d'outro metal". El tabernáculo de mayor tamaño, el exterior, tenía otro chapitel de carácter semejante, pero decorado en cada frente con una claraboya redonda y sustentado por una estructura de madera cuyas puertas pintadas imitaban los tejidos esculturados con la heráldica castellano-leonesa y cerradas adoptaban el perfil de un arco coronado por un florón ${ }^{71}$.

70 M.J. SANZ SERRANO, op. cit., 1998, p. 57. T. LAGUNA PAÚL, op. cit., 2001b, pp. 243-245 y 250251; O. PÉREZ MONZÓN, op. cit., 2007, p. 394.

71 T. LAGUNA PAÚL, op. cit., 2013, pp. 65-70. J. GUERRERO LOVILLO, Las cantigas, estudio arqueológico de sus miniaturas, Madrid, 1949, pp. 288-291; G. MENÉNDEZ PIDAL, La España del siglo XIII leída en imágenes, Madrid, 1986, pp. 122-123; y A. GARCÍA CUADRADO, Las Cantigas. El códice de Florencia, Murcia, 1993, pp. 240. 


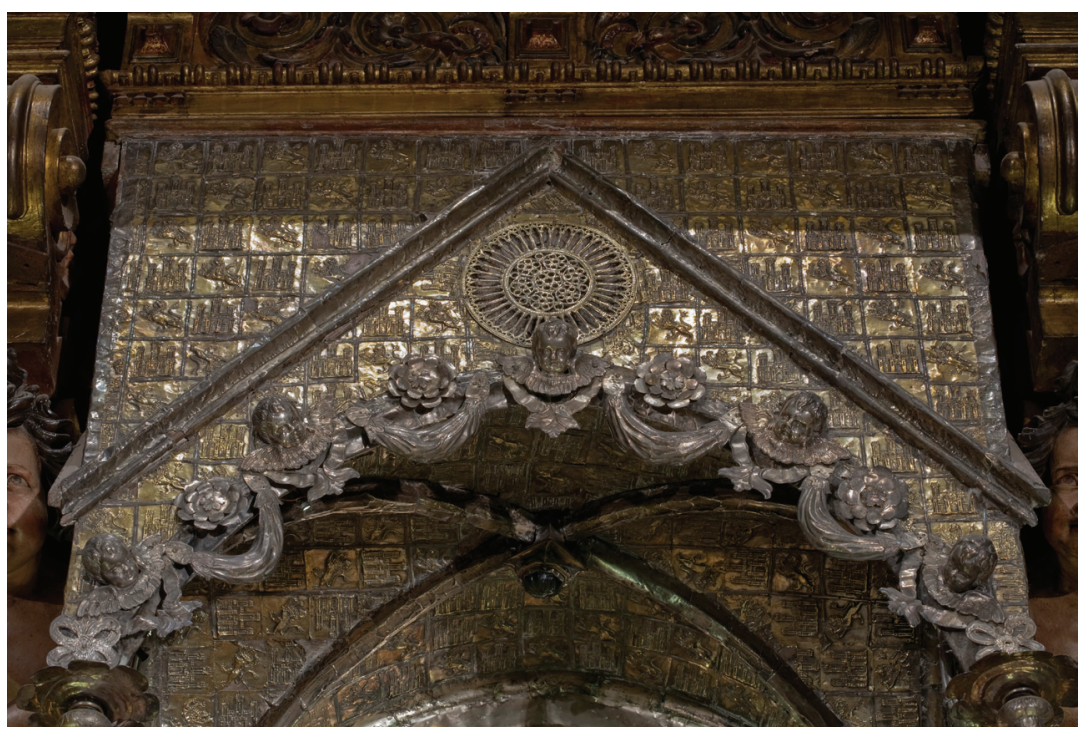

Fig. 11. Catedral de Sevilla, capilla Real. Restos del chapitel gótico del tabernáculo exterior de la Virgen de los Reyes, atribuido a Jorge de Toledo (h. 1279), incorporados al dosel-tabernáculo de la Virgen del retablo de Luis Ortiz de Vargas. Placa de fondo del trono realizada por Manuel Seco Velasco en 1935 y diseño de Sebastián Bandarán. (C) Teresa Laguna.

La altura de los dos tabernáculos góticos atribuidos a Jorge de Toledo alcanzarían aproximadamente dos metros de altura, tendrían una silueta semejante a la representada en la cantiga 29 del Códice Rico y en 1579 los instalaron en el nicho del altar mayor de la capilla Real renacentista. Este hueco acogió desplegados los batientes de madera dorada del mueble exterior, cuyos castillos y leones pintados evocó después el retablo de Luis de Vargas (1643-1644) en la retícula del fondo y en las puertas barrocas que ocultan, puntualmente, la Imagen y contribuyeron a mantener parte de la escenografía medieval adaptándola a la estética de época moderna $^{72}$. El dosel de madera actual tiene embutido parte del tabernáculo gótico exterior (fig. 11), conserva aproximadamente cien placas del enchapado medieval de plata dorada de 6 x $6 \mathrm{~cm}$. y uno de los tres rosetones góticos, cuyo diseño recuerda otros objetos suntuarios contemporáneos como, por ejemplo, el relicario del santo sepulcro de la catedral de Pamplona, el templete del arca relicario de la Santa Capilla fechado hacia 1250, dibujado por Roger de Gaignières a finales del siglo XVIII. La bóveda del chapitel argénteo actual recuerda la decoración de las cubiertas góticas pintadas con emblemas heráldicos en la nave de san Juan evangelista

72 M.J. SANZ SERRANO, op. cit., 1998, p. 60; A. MORALES MARTÍNEZ, "La capilla Real de Sevilla, del 'Plateresco' al Barroco", A. JIMÉNEZ (ed.), La capilla Real. XIX Aula Hernán Ruiz, Sevilla, 2012, pp. 243-244; y F. HALCÓN, "El retablo barroco sevillano de la primera mitad del siglo XVII", F. HALCÓN, F. HERRERA y A. RECIO, El retablo sevillano. Desde sus orígenes a la actualidad. Sevilla, 2010, p. 200. 
del monasterio cisterciense de santa María la Real de las Huelgas (h. 1260-1270) ${ }^{73}$ y el rosetón gótico fusiona los elementos polilobulados de la rosa de la fachada norte del crucero de la catedral de Laon (1180-1190) con la arquería de la galería alta de la fachada occidental de Notre Dame de París (1208-1220). Estas referencias al templete parisino destruido en $1791 \mathrm{y}$ a las empresas del reinado de Luis IX manifiestan, al igual que las Tablas relicario de Alfonso X, la llegada y asimilación de los modelos desde París hasta Sevilla, en unas obras y empresas integradoras de tendencias que equiparan los encargos suntuarios alfonsíes a otros de la vanguardia artística contemporánea ${ }^{74}$.

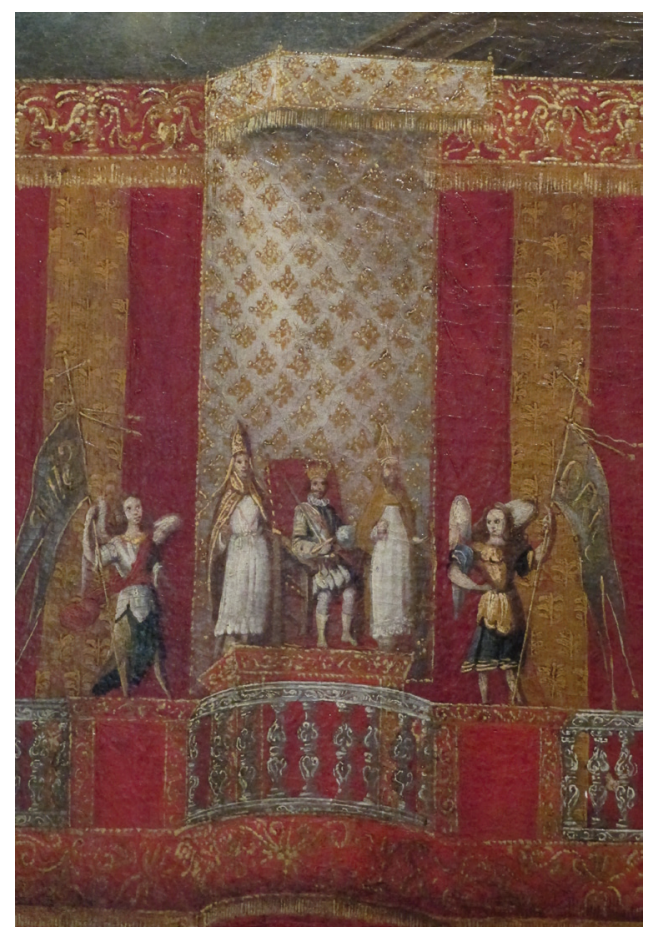

Fig. 12. Representación del simulacro de Fernando III hacia 1662. Detalle de la Procesión de la consagración de la Iglesia del Sagrario y las fiestas por el Breve del papa Alejandro VII favorable a la Inmaculada Concepción en 1662. Catedral de Sevilla, INV. 4109101110832.000 .

73 T. LAGUNA PAÚL, op. cit., 2009a, pp. 225, 236; F. GUTIÉRREZ BAÑOS, Aportación al estudio de la pintura de estilo gótico lineal en Castilla y León: precisiones cronológicas y corpus de la pintura mural y sobre tabla, Madrid, 2006, vol. II, pp. 275-278; y op. cit, 2011a, pp. 381-382.

74 T. LAGUNA PAÚL, op. cit., 2012, pp. 183-186; R. CÓMEZ RAMOS, “Tradición y renovación artística en la Castilla del siglo XIII", Alcanate, 3 (2002-2003), pp. 135-163;y "La arquitectura en la miniatura de la corte de Alfonso X", Alcanate, 6 (2008-2009), pp. 207-208; L. MOLINA LÓPEZ, "La entrada del modelo arquitectónico federiciano en el reino de Castilla: la torre de Don Fadrique", Anales de Historia del Arte, 20/ extra-2, (2010), pp. 185-200; "y Viaje a Italia a través de las Cantigas historiadas de Alfonso X el Sabio", Anales de Historia del Arte 22/extra (2012), pp. 319-330. 
Estas devociones reales e imagen pública en Sevilla quedarían incompletas si se omitiera la presencia en la capilla Real de las reliquias del cuerpo de San Leandro quien, según la tradición, reveló a Fernando III el lugar donde fue enterrado cerca de la puerta de Córdoba, localizado por el monarca en la segunda de sus incursiones furtivas. Las fuentes y textos relativos a la invención de estas reliquias tampoco podemos encontrarlas antes del siglo XVI y sabemos por el manuscrito de la Traslación de la imagen de Nuestra Señora de los Reyes y cuerpo de San Leandro $y$ de los cuerpos reales a la Real Capilla de la Santa Iglesia de Sevilla en 1579 que las depositaron en el altar de la Virgen dentro de una hornacina cerrada con unos batientes manieristas de madera dorada que, situada detrás del frontal barroco, guardaba también en el siglo XVIII la espada de Fernando III y otras reliquias, ya que la realización de la escultura de Pedro Roldán en 1671 relegó a la memoria del archivo las representaciones reales medievales ${ }^{75}$ (fig.12). Estas reliquias del cuerpo de san Leandro debieron estar siempre vinculadas con el altar de santa María, incluso pudieron consagrar con ellas este altar, donde serían veneradas por los fieles especialmente en su festividad y octavas, celebradas en la catedral desde 1256. En algún momento indeterminado, o bien en el transcurso de los cambios derivados del repartimiento de la catedral mudéjar, separarían la cabeza para realizar otro relicario que facilitaría su exposición y la reverencia de los fieles. A comienzos del siglo XV este segundo relicario era un busto de plata y esmaltes con los escudos del arzobispo Alonso de Ejea (1403-1417). El busto relicario, descrito en el inventario de Fábrica de 1596, fue renovado en el siglo XVIII por el platero José Guerrero y Alcántara $\mathrm{y}$, entonces, depositaron bajo la mitra parte del cráneo del santo obispo y en el interior del broche del pecho colocaron otra de San Pío que corresponde a la identificación actual de esta obra barroca ${ }^{76}$. Este testimonio documental supone otra huella, otro vestigio de la revitalización de las tradiciones, leyendas y del culto a los santos de época visigoda, del goticismo religioso que en las mismas fechas salvaguardó el pilar del altar de Santa María de la Antigua y preservó la pintura medieval hasta nuestros días.

75 MALDONADO DAVILA, Disertación histórica de la capilla Real de Sevilla. Lib. 4, cap. 10. D. ORTIZ DE ZÚÑIGA, op. cit., 1795, T. I, pp. 47, 218. F. DE SIGÜENZA, Traslación de la imagen de Nuestra Señora de los Reyes y cuerpo de San Leandro y de los cuerpos reales a la Real Capilla de la Santa Iglesia de Sevilla, 1579, F. GARCIA DE LA CONCHA (Ed.), Sevilla, 1996, p. 96.; J. GESTOSO, op. cit., 1890, T. I, pp. 431-432.

76 T. LAGUNA PAÚL, op. cit., 2012, p. 219. 